\title{
Preindustrial to present-day changes in tropospheric hydroxyl radical and methane lifetime from the Atmospheric Chemistry and Climate Model Intercomparison Project (ACCMIP)
}

\author{
V. Naik ${ }^{1}$, A. Voulgarakis ${ }^{2}$, A. M. Fiore ${ }^{3}$, L. W. Horowitz ${ }^{4}$, J.-F. Lamarque ${ }^{5}$, M. Lin ${ }^{4,6}$, M. J. Prather ${ }^{7}$, P. J. Young, ${ }^{8,9, *}$, \\ D. Bergmann ${ }^{10}$, P. J. Cameron-Smith ${ }^{10}$, I. Cionni ${ }^{11}$, W. J. Collins ${ }^{12, * *}$, S. B. Dalsøren ${ }^{13}$, R. Doherty ${ }^{14}$, V. Eyring ${ }^{15}$, \\ G. Faluvegi ${ }^{16}$, G. A. Folberth ${ }^{12}$, B. Josse ${ }^{17}$, Y. H. Lee ${ }^{16}$, I. A. MacKenzie $^{14}$, T. Nagashima ${ }^{18}$, T. P. C. van Noije ${ }^{19}$, \\ D. A. Plummer ${ }^{20}$, M. Righi ${ }^{15}$, S. T. Rumbold ${ }^{12}$, R. Skeie ${ }^{13}$, D. T. Shindell ${ }^{16}$, D. S. Stevenson ${ }^{14}$, S. Strode ${ }^{21}$, K. Sudo ${ }^{22}$, \\ S. Szopa $^{23}$, and G. Zeng ${ }^{24}$ \\ ${ }^{1}$ UCAR/NOAA Geophysical Fluid Dynamics Laboratory, Princeton, New Jersey, USA \\ ${ }^{2}$ Department of Physics, Imperial College, London, UK \\ ${ }^{3}$ Department of Earth and Environmental Sciences and Lamont-Doherty Earth Observatory of Columbia University, \\ Palisades, New York, USA \\ ${ }^{4}$ NOAA Geophysical Fluid Dynamics Laboratory, Princeton, New Jersey, USA \\ ${ }^{5}$ National Center for Atmospheric Research, Boulder, Colorado, USA \\ ${ }^{6}$ Atmospheric and Oceanic Sciences, Princeton University, New Jersey, USA \\ ${ }^{7}$ Department of Earth System Science, University of California, Irvine, California, USA \\ ${ }^{8}$ Cooperative Institute for Research in the Environmental Sciences, University of Colorado-Boulder, Boulder, Colorado, USA \\ ${ }^{9}$ Chemical Sciences Division, NOAA Earth System Research Laboratory, Boulder, Colorado, USA \\ ${ }^{10}$ Lawrence Livermore National Laboratory, Livermore, California, USA \\ ${ }^{11}$ Agenzia nazionale per le nuove tecnologie, l'energia e lo sviluppo economico sostenibile (ENEA), Bologna, Italy \\ ${ }^{12}$ Hadley Centre for Climate Prediction, Met Office, Exeter, UK \\ ${ }^{13}$ CICERO, Center for International Climate and Environmental Research-Oslo, Oslo, Norway \\ ${ }^{14}$ School of Geosciences, University of Edinburgh, Edinburgh, UK \\ ${ }^{15}$ Deutsches Zentrum für Luft- und Raumfahrt, Institut für Physik der Atmosphäre, Oberpfaffenhofen, Germany \\ ${ }^{16}$ NASA Goddard Institute for Space Studies, New York City, New York, USA \\ ${ }^{17}$ GAME/CNRM, Météo-France, CNRS - Centre National de Recherches Météorologiques, Toulouse, France \\ ${ }^{18}$ National Institute for Environmental Studies, Tsukuba-shi, Ibaraki, Japan \\ ${ }^{19}$ Royal Netherlands Meteorological Institute, De Bilt, the Netherlands \\ ${ }^{20}$ Canadian Centre for Climate Modeling and Analysis, Environment Canada, Victoria, British Columbia, Canada \\ ${ }^{21}$ NASA Goddard Space Flight Center, Greenbelt, Maryland, USA and Universities Space Research Association, Columbia, \\ MD, USA \\ ${ }^{22}$ Department of Earth and Environmental Science, Graduate School of Environmental Studies, Nagoya University, \\ Nagoya, Japan \\ ${ }^{23}$ Laboratoire des Sciences du Climat et de l'Environnement, LSCE/CEA/CNRS/UVSQ/IPSL, France \\ ${ }^{24}$ National Institute of Water and Atmospheric Research, Lauder, New Zealand \\ * now at: Lancaster Environment Centre, Lancaster University, Lancaster, UK \\ ** now at: Department of Meteorology, University of Reading, Reading, UK
}

Correspondence to: V. Naik (vaishali.naik@noaa.gov) 
Abstract. We have analysed time-slice simulations from 17 global models, participating in the Atmospheric Chemistry and Climate Model Intercomparison Project (ACCMIP), to explore changes in present-day (2000) hydroxyl radical $(\mathrm{OH})$ concentration and methane $\left(\mathrm{CH}_{4}\right)$ lifetime relative to preindustrial times (1850) and to 1980. A comparison of modeled and observation-derived methane and methyl chloroform lifetimes suggests that the present-day global multimodel mean $\mathrm{OH}$ concentration is overestimated by 5 to $10 \%$ but is within the range of uncertainties. The models consistently simulate higher $\mathrm{OH}$ concentrations in the Northern Hemisphere $(\mathrm{NH})$ compared with the Southern Hemisphere ( $\mathrm{SH})$ for the present-day (2000; inter-hemispheric ratios of 1.13 to 1.42), in contrast to observation-based approaches which generally indicate higher $\mathrm{OH}$ in the $\mathrm{SH}$ although uncertainties are large. Evaluation of simulated carbon monoxide $(\mathrm{CO})$ concentrations, the primary sink for $\mathrm{OH}$, against ground-based and satellite observations suggests low biases in the $\mathrm{NH}$ that may contribute to the high north-south $\mathrm{OH}$ asymmetry in the models. The models vary widely in their regional distribution of present-day $\mathrm{OH}$ concentrations (up to $34 \%$ ). Despite large regional changes, the multi-model global mean (mass-weighted) $\mathrm{OH}$ concentration changes little over the past $150 \mathrm{yr}$, due to concurrent increases in factors that enhance $\mathrm{OH}$ (humidity, tropospheric ozone, nitrogen oxide $\left(\mathrm{NO}_{\mathrm{x}}\right)$ emissions, and UV radiation due to decreases in stratospheric ozone), compensated by increases in $\mathrm{OH}$ sinks (methane abundance, carbon monoxide and non-methane volatile organic carbon (NMVOC) emissions). The large inter-model diversity in the sign and magnitude of preindustrial to present-day $\mathrm{OH}$ changes (ranging from a decrease of $12.7 \%$ to an increase of $14.6 \%$ ) indicate that uncertainty remains in our understanding of the long-term trends in $\mathrm{OH}$ and methane lifetime. We show that this diversity is largely explained by the different ratio of the change in global mean tropospheric $\mathrm{CO}$ and $\mathrm{NO}_{\mathrm{x}}$ burdens $\left(\Delta \mathrm{CO} / \Delta \mathrm{NO}_{\mathrm{x}}\right.$, approximately represents changes in $\mathrm{OH}$ sinks versus changes in $\mathrm{OH}$ sources) in the models, pointing to a need for better constraints on natural precursor emissions and on the chemical mechanisms in the current generation of chemistry-climate models. For the 1980 to 2000 period, we find that climate warming and a slight increase in mean $\mathrm{OH}(3.5 \pm 2.2 \%)$ leads to a $4.3 \pm 1.9 \%$ decrease in the methane lifetime. Analysing sensitivity simulations performed by 10 models, we find that preindustrial to presentday climate change decreased the methane lifetime by about four months, representing a negative feedback on the climate system. Further, we analysed attribution experiments performed by a subset of models relative to 2000 conditions with only one precursor at a time set to 1860 levels. We find that global mean $\mathrm{OH}$ increased by $46.4 \pm 12.2 \%$ in response to preindustrial to present-day anthropogenic $\mathrm{NO}_{\mathrm{x}}$ emission increases, and decreased by $17.3 \pm 2.3 \%, 7.6 \pm 1.5 \%$, and $3.1 \pm 3.0 \%$ due to methane burden, and anthropogenic $\mathrm{CO}$, and NMVOC emissions increases, respectively.

\section{Introduction}

The hydroxyl radical $(\mathrm{OH})$ is the dominant oxidizing agent in the global troposphere as it reacts with most pollutants (Levy, 1971; Logan et al., 1981; Thompson, 1992), thereby controlling their atmospheric abundance and lifetime. Any changes in $\mathrm{OH}$ affect the tropospheric chemical lifetime of methane $\left(\mathrm{CH}_{4}\right)$, the most abundant organic species in the atmosphere and a potent greenhouse gas, since reaction with $\mathrm{OH}$ is the primary mechanism by which it is removed from the atmosphere. Complex series of chemical reactions involving tropospheric ozone $\left(\mathrm{O}_{3}\right)$, methane, carbon monoxide (CO), non-methane volatile organic compounds (NMVOCs), and nitrogen oxides $\left(\mathrm{NO}_{\mathrm{x}}=\mathrm{NO}+\mathrm{NO}_{2}\right)$, as well as the levels of solar radiation and humidity, determine the tropospheric abundance of $\mathrm{OH}$ (Logan et al., 1981; Thompson, 1992). The more-than-doubling of global methane abundance since preindustrial times (Petit et al., 1999; Loulergue et al., 2008; Sapart et al., 2012), combined with the rise in emissions of $\mathrm{NO}_{\mathrm{x}}, \mathrm{CO}$ and NMVOCs (Lamarque et al., 2010), is likely to have had some influence on $\mathrm{OH}$ and consequently on the chemical methane lifetime in the past $150 \mathrm{yr}$. We analyse results from global chemistry-climate models participating in the Atmospheric Chemistry and Climate Model Intercomparison Project (ACCMIP; see www.giss.nasa.gov/projects/ accmip) to investigate the changes in tropospheric $\mathrm{OH}$ abundance and its drivers, and methane lifetime over the historical period between 1850 and 2000 .

Primary production of tropospheric $\mathrm{OH}$ occurs when electronically excited $\mathrm{O}\left({ }^{1} \mathrm{D}\right)$ atoms, produced by ozone photolysis at wavelengths less than $340 \mathrm{~nm}$, react with water vapor:

$$
\begin{aligned}
& \mathrm{O}_{3}+h v(\lambda<340 \mathrm{~nm}) \rightarrow \mathrm{O}\left({ }^{1} \mathrm{D}\right)+\mathrm{O}_{2} \\
& \mathrm{O}\left({ }^{1} \mathrm{D}\right)+\mathrm{H}_{2} \mathrm{O} \rightarrow 2 \mathrm{OH}
\end{aligned}
$$

Therefore, production of $\mathrm{OH}$ is highest in the tropical lower to middle troposphere, reflecting the combined impact of high levels of water vapour, and low stratospheric ozone column, meaning higher incident ultraviolet (UV) radiation (Logan et al., 1981; Spivakovsky et al., 2000; Lelieveld et al., 2002). $\mathrm{OH}$ has a tropospheric lifetime on the order of seconds, reacting rapidly with $\mathrm{CO}$, methane and NMVOCs to produce $\mathrm{HO}_{2}$ or an organic peroxy radical $\left(\mathrm{RO}_{2}\right)$, key species for the secondary production of $\mathrm{OH}$ :

$$
\begin{gathered}
\mathrm{OH}+\mathrm{CO}\left(+\mathrm{O}_{2}\right) \rightarrow \mathrm{HO}_{2}+\mathrm{CO}_{2} \\
\mathrm{OH}+\mathrm{RH}\left(+\mathrm{O}_{2}\right) \rightarrow \mathrm{RO}_{2}+\mathrm{H}_{2} \mathrm{O}
\end{gathered}
$$

Secondary formation of $\mathrm{OH}$ can occur in the presence of $\mathrm{NO}_{\mathrm{x}}$ since $\mathrm{NO}$ reacts with $\mathrm{HO}_{2}$ or $\mathrm{RO}_{2}$ to recycle $\mathrm{OH}$ (Crutzen, 1973; Zimmerman et al., 1978):

$$
\begin{aligned}
& \mathrm{HO}_{2}+\mathrm{NO} \rightarrow \mathrm{NO}_{2}+\mathrm{OH} \\
& \mathrm{RO}_{2}+\mathrm{NO}\left(+\mathrm{O}_{2}\right) \rightarrow \mathrm{R}^{\prime} \mathrm{CHO}+\mathrm{NO}_{2}+\mathrm{OH}
\end{aligned}
$$

Additional $\mathrm{OH}$ is produced because $\mathrm{NO}_{2}$ can photolyse resulting in the formation of ozone, the primary precursor to 
OH (Hameed et al., 1979):

$$
\begin{aligned}
& \mathrm{NO}_{2}+h v(\lambda<420 \mathrm{~nm}) \rightarrow \mathrm{O}\left({ }^{3} \mathrm{P}\right)+\mathrm{NO} \\
& \mathrm{O}\left({ }^{3} \mathrm{P}\right)+\mathrm{O}_{2}+\mathrm{M} \rightarrow \mathrm{O}_{3}+\mathrm{M}
\end{aligned}
$$

This secondary production of $\mathrm{OH}$ via radical recycling by $\mathrm{NO}_{\mathrm{x}}$ (Reactions R5-R6) plays a more important role at higher latitudes where incoming solar radiation and water vapour are less abundant, and $\mathrm{NO}_{\mathrm{x}}$ and ozone concentrations are generally higher (Logan et al., 1981; Spivakovsky et al., 2000; Lelieveld et al., 2002). Conversely, in clean air the reaction chain can be terminated by the loss of $\mathrm{HO}_{2}$ (Reaction $\mathrm{R} 3$ ) and $\mathrm{RO}_{2}$ radicals (Reaction $\mathrm{R} 4$ ) via

$$
\begin{aligned}
& \mathrm{HO}_{2}+\mathrm{HO}_{2} \rightarrow \mathrm{H}_{2} \mathrm{O}_{2}+\mathrm{O}_{2} \\
& \mathrm{RO}_{2}+\mathrm{HO}_{2} \rightarrow \mathrm{ROOH}+\mathrm{O}_{2}
\end{aligned}
$$

Recent laboratory studies have indicated that reaction of selected $\mathrm{RO}_{2}$ radicals with $\mathrm{HO}_{2}$ can also produce $\mathrm{OH}$ at significant yields (Dillon and Crowley, 2008 and references therein):

$$
\mathrm{RO}_{2}+\mathrm{HO}_{2} \rightarrow \mathrm{RO}+\mathrm{OH}+\mathrm{O}_{2} .
$$

This has implications for $\mathrm{NO}_{\mathrm{x}}$ poor, NMVOC rich environments where radical recycling via (R5) and (R6) is suppressed. Several chemical mechanisms, proposed for the cycling of $\mathrm{HO}_{2}$ to $\mathrm{OH}$ under low- $\mathrm{NO}_{\mathrm{x}}$, high-NMVOC conditions, are yet to satisfactorily reconcile discrepancies between modeled and observed $\mathrm{OH}$ indicating large uncertainties in our understanding of the tropospheric photochemical oxidation (Stone et al., 2012 and references therein). Chemical mechanisms describing Reaction (R11) are not implemented in the models considered here. Temperature plays a key role by controlling reaction rates and tropospheric water vapour abundances. Overall, the global mean tropospheric $\mathrm{OH}$ represents a balance between its sources (water vapor, tropospheric ozone, $\mathrm{NO}_{\mathrm{x}}$ contributing to secondary $\mathrm{OH}$ production) and sinks (methane, CO, NMVOCs), that is modulated by overhead ozone column (UV radiation) and temperature.

The extent to which tropospheric $\mathrm{OH}$ level has changed due to anthropogenic activity is highly uncertain. Observational evidence of preindustrial to present-day changes in $\mathrm{OH}$ is sparse and questionable. For example, Staffelbach et al. (1991) postulated that $\mathrm{OH}$ has decreased by $30 \%$ in the present-day relative to preindustrial times using measurements of formaldehyde to methane $\left(\mathrm{HCHO} / \mathrm{CH}_{4}\right)$ ratio in ice cores as potential proxy of the past $\mathrm{OH}$ concentration. However, Sofen et al. (2011) note that ice-core formaldehyde is sensitive to post-depositional processing that impedes quantitative interpretation of past atmospheric conditions. Previous modeling of changes in tropospheric mean $\mathrm{OH}$ abundance from preindustrial to present-day range from increases of 6 to $15 \%$ (Crutzen and Bruhl, 1993; Martinerie et al., 1995; Berntsen et al., 1997), to no change (Pinto and Khalil, 1991; Lelieveld et al., 2004), to decreases of 5 to
$33 \%$ (Thompson et al., 1992; Wang and Jacob, 1998; Mickley et al., 1999; Hauglustaine and Brasseur, 2001; Grenfell et al., 2001; Lelieveld et al., 2002; Shindell et al., 2003; Wong et al., 2004; Lamarque et al., 2005a; Shindell et al., 2006a; Skeie et al., 2010; Sofen et al., 2011; John et al., 2012). As evident from these wide-ranging results, there is no consensus on how tropospheric $\mathrm{OH}$ abundance has evolved in the past 150 years, with a consequent lack of agreement on the trends in methane lifetime during the historical period (Table 1 of John et al., 2012).

Much effort has been placed on understanding the longterm trends and interannual variability in atmospheric $\mathrm{OH}$ concentrations over the past two to three decades. Long-term site-specific measurements of $\mathrm{OH}$ concentrations provide insight on its trend/variability for specific chemical regimes (Rohrer and Berresheim, 2006). For an understanding of the changes in global mean $\mathrm{OH}$, one must rely on measurements of trace gases whose emissions are well known and whose primary sink is $\mathrm{OH}$. Accurate long-term measurements of the industrial chemical 1,1,1-trichloroethane (methyl chloroform $\mathrm{CH}_{3} \mathrm{CCl}_{3}$ ) (Prinn et al., 1995, 2000, 2001; Montzka et al., 2000) in the atmosphere and an assumption of accurate emissions inventories (Montzka and Fraser, 2003) enable estimates of trends and interannual variability in tropospheric abundance of $\mathrm{OH}$ to be inferred from observed changes in $\mathrm{CH}_{3} \mathrm{CCl}_{3}$ (Prinn et al., 1995, 2001, 2005; Krol et al., 1998; Krol and Lelieveld, 2003; Bousquet et al., 2005; Montzka et al., 2000, 2011). Large changes in $\mathrm{OH}$ in the past three decades inferred from $\mathrm{CH}_{3} \mathrm{CCl}_{3}$ observations (Prinn et al., 2001; Bousquet et al., 2005) have been debated in the literature (Krol and Lelieveld, 2003; Lelieveld et al., 2004) as they have been difficult to reconcile based on results from current theoretical models that suggest small increases in global OH concentrations for the 1980-2000 period (Karlsdóttir and Isaksen, 2000; Dentener et al., 2003; Dalsøren and Isaksen, 2006; Hess and Mahowald, 2009; John et al., 2012; Holmes et al., 2013). In a more recent analysis of $\mathrm{CH}_{3} \mathrm{CCl}_{3}$ measurements since 1998 (a period with diminished atmospheric $\mathrm{CH}_{3} \mathrm{CCl}_{3}$ gradients due to phasing out of its emissions under the Montreal Protocol), Montzka et al. (2011) infer small interannual $\mathrm{OH}$ variability and attribute previously estimated large year-to-year $\mathrm{OH}$ variations before 1998 to uncertainties in $\mathrm{CH}_{3} \mathrm{CCl}_{3}$ emissions. Further, using observations of methane and $\delta^{13} \mathrm{C}_{-} \mathrm{CH}_{4}$, Monteil et al. (2011) find that moderate $(<5 \%)$ increases in global $\mathrm{OH}$ are needed to explain the observed slowdown in the growth rate of atmospheric methane, thus incompatible with the previously estimated observation-based reduction in $\mathrm{OH}$ in 2000 relative to 1980.

Previous multi-model studies have focused on intercomparison of changes in atmospheric composition with reference to $\mathrm{OH}$ and methane lifetime in the context of changes in ozone and CO (Stevenson et al., 2006; Shindell et al., 2006b). To our knowledge, our study provides the first multimodel estimates of historical $\mathrm{OH}$ changes, thereby demonstrating our current level of understanding of historical trends 
in $\mathrm{OH}$ and methane lifetime based on the current generation of chemistry-climate models (CCMs). Here our goals are to (1) evaluate the present-day (2000) OH in the models, (2) explore changes in $\mathrm{OH}$ and methane lifetimes since preindustrial times, and (3) investigate the impact of individual factors (climate and ozone precursor emissions) driving these changes. A parallel study compares future projections of $\mathrm{OH}$ and methane lifetime in the ACCMIP models (Voulgarakis et al., 2013). We provide a summary of models used, the experiments they performed, and our analysis approach in Sect. 2. Historical $\mathrm{OH}$ and methane lifetime are presented in Sect. 3. Changes in $\mathrm{OH}$, methane lifetime, and their driving factors in the present-day (2000) relative to preindustrial (1850) and to 1980 are discussed in Sects. 4 and 5, respectively. The sensitivity of $\mathrm{OH}$ and methane lifetime to historical change in climate, and changes in methane burden and emissions are presented in Sects. 6 and 7, respectively, with conclusions drawn in Sect. 8.

\section{Methodology}

\subsection{ACCMIP models}

We analyse results from 17 different global models to investigate how $\mathrm{OH}$ and methane lifetime in the present-day has changed relative to 1850 and to 1980 . In other studies, ACCMIP results have been analysed to compare changes in atmospheric composition from 1850 to 2100 with a focus on physical climate variables (Lamarque et al., 2013), tropospheric ozone (Young et al., 2013) and its radiative forcing (Stevenson et al., 2013; Bowman et al., 2013), black carbon (Lee et al., 2013), and on aerosol radiative forcing (Shindell et al., 2013). Detailed descriptions of ACCMIP models are provided by Lamarque et al. (2013).

Nearly all the models are run as coupled chemistry-climate models (CCMs), driven by climatological monthly mean sea surface temperatures (SSTs) and sea ice coverage (SIC) either from observations or from the corresponding coupled ocean-atmosphere model integrations submitted to the Coupled Model Intercomparison Project Phase 5 (CMIP5). Three models, namely CICERO-OsloCTM2, MOCAGE, and TM5 are chemistry transport models (CTMs) driven by meteorological fields from an offline reanalysis or output from a general circulation model. Meteorological fields used to run CICERO-OsloCTM2 and TM5 did not vary across timeslice simulations. GISS-E2-R and GISS-E2-R-TOMAS are two different configurations of the same model - GISS-E2$\mathrm{R}$ is a fully interactive coupled ocean-atmosphere-chemistry model with a simple mass-based representation of aerosols, while GISS-E2-R-TOMAS uses SSTs and SIC from GISSE2-R with a more detailed aerosol microphysics scheme. Similarly, HadGEM2 and HadGEM2-ExtTC are the same, except HadGEM2 includes a simple tropospheric chemistry scheme, while HadGEM2-ExtTC incorporates a more detailed chemistry scheme with many more hydrocarbons.

Key characteristics of the models relevant for simulating atmospheric $\mathrm{OH}$ and methane lifetime are presented in Table A1 of Voulgarakis et al. (2013). Briefly, anthropogenic and biomass burning emissions are taken from Lamarque et al. (2010) and vary over the historical period (Young et al., 2013). Natural emissions for $\mathrm{NO}_{\mathrm{x}}, \mathrm{CO}$, and NMVOCs were specified from different sources and are one of the major sources of diversity in model results (Table A1; source-wise emissions for 2000 implemented in the models are summarized in Table S1 in the Supplement). Other sources of differences across the models are expected to result from diversity in the complexity of NMVOC chemistry (mechanisms include a range from 16 to 100 species), stratospheric ozone representations, and resulting impacts on ozone photolysis rates (see Table 3 of Lamarque et al. (2013) for further details). Most models prescribe methane values at the surface (but allow it to undergo chemical processing elsewhere in the atmosphere) from the historical reconstruction of Meinshausen et al. (2011) though a few models use alternative approaches. Two models (STOC-HadAM3 and UM-CAM) apply a uniform global concentration and another (LMDzORINCA) applies emission fluxes. The temperature-dependent rate coefficient $\left(k_{\mathrm{CH}_{4}+\mathrm{OH}}\right)$ for methane oxidation (R4) applied in most models is from Sander et al. (2011). Global and annual average $k_{\mathrm{CH}_{4}+\mathrm{OH}}$ implemented in the models are shown in Table S2 in the Supplement. The coefficient of variation $(\mathrm{CV}$; standard deviation as a percentage of the multi-model mean) for $k_{\mathrm{CH}_{4}+\mathrm{OH}}$ across models is less than $2 \%$, suggesting that the impact of differences in temperature across models on $k_{\mathrm{CH}_{4}+\mathrm{OH}}$ is minimal and is, therefore, unlikely to contribute to the diversity in methane lifetime shown later.

\subsection{Simulations}

We analysed three time-slice simulations over the historical period - 1850, 1980 and 2000, performed by 16 models (HadGEM2-ExtTC performed only attribution simulations described below). The models were typically run for 4 to $10 \mathrm{yr}$ for each time-slice, though GEOSCCM performed $14 \mathrm{yr}$ integrations, CICERO-OsloCTM2 and TM5 performed single year simulations (the reference year for TM5 presentday simulation being 2006), and GISS-E2-R and LMDzORINCA were run transiently for the entire historical period. For the analysis performed here, we averaged results over all the available years of each of the three historical timeslices. In the case of the GISS-E2-R and LMDzORINCA models, we averaged years centered on the time-slice (except average over 1850-1859 was used for 1850 and average over 1996-2000 was used for 2000 for LMDzORINCA). Interannual variability in $\mathrm{OH}$ is not explicitly addressed here because ACCMIP simulations were designed to address only long-term changes. 
Table 1. Global total methane burden, airmass-weighted tropospheric mean $\mathrm{OH}$, and tropospheric methane lifetime $\left(\tau_{\mathrm{CH}_{4}}\right)$ for 1850 , 1980 and 2000 time-slices, and tropospheric $\mathrm{CH}_{3} \mathrm{CCl}_{3}$ lifetime $\left(\tau_{\mathrm{MCF}}\right)$ for 2000 time-slice from 16 models. The troposphere is assumed to extend from surface to $200 \mathrm{hPa}$ for each model's grid. A cell with * means that the model did not report that quantity. Multi-model mean (MMM) with standard deviation (STD), coefficient of variation (CV; standard deviation as percentage of the multi-model mean), and observation-derived estimates of $\tau_{\mathrm{CH}_{4}}$ and $\tau_{\mathrm{MCF}}$ (based on Prinn et al. (2005) and Prather et al.(2012)) are shown in the last three rows.

\begin{tabular}{|c|c|c|c|c|c|c|c|c|c|c|}
\hline \multirow[b]{2}{*}{ Models } & \multicolumn{3}{|c|}{$\begin{array}{c}\mathrm{CH}_{4} \text { Burden } \\
(\mathrm{Tg})\end{array}$} & \multicolumn{3}{|c|}{$\begin{array}{c}\mathrm{OH} \\
\left(10^{5} \mathrm{molec}^{-3}\right)\end{array}$} & \multicolumn{3}{|c|}{$\begin{array}{c}\tau_{\mathrm{CH}_{4}} \\
\text { (years) }\end{array}$} & \multirow{2}{*}{$\begin{array}{l}\tau_{\mathrm{MCF}} \\
\text { (years) }\end{array}$} \\
\hline & 1850 & 1980 & 2000 & 1850 & 1980 & 2000 & 1850 & 1980 & 2000 & \\
\hline CESM-CAM-superfast (CE) & 2191 & 4431 & 4902 & 12.1 & 12.3 & 12.8 & 9.3 & 8.8 & 8.4 & 4.9 \\
\hline CICERO-OsloCTM2 (CI) & 2089 & 4286 & 4779 & 11.7 & 10.3 & 10.4 & 9.1 & 10.1 & 10.0 & 5.8 \\
\hline CMAM (CM) & 2179 & 4260 & 4846 & 11.9 & 10.6 & 10.7 & 8.7 & 9.7 & 9.4 & 5.5 \\
\hline EMAC (EM) & 2163 & 4235 & 4788 & 12.7 & 11.3 & 11.7 & 8.9 & 9.6 & 9.1 & 5.4 \\
\hline GEOSCCM (GE) & 2178 & 4258 & 4818 & 13.0 & 11.3 & 11.3 & 8.6 & 9.7 & 9.6 & 5.6 \\
\hline GFDL-AM3 (GF) & 2221 & 4234 & 4809 & 12.7 & 11.4 & 11.7 & 8.9 & 9.7 & 9.4 & 5.5 \\
\hline GISS-E2-R (GI) & 2188 & 4226 & 4793 & 9.8 & 9.9 & 10.5 & 11.9 & 11.4 & 10.6 & 6.2 \\
\hline GISS-E2-R-TOMAS (GT) & 2189 & 4499 & 4816 & 11.6 & 12.0 & 12.7 & 10.4 & 9.8 & 9.2 & 5.3 \\
\hline HadGEM2 (HA) & 2155 & 4133 & 4680 & 8.1 & 7.8 & 8.1 & 11.6 & 12.1 & 11.6 & 6.7 \\
\hline LMDzORINCA (LM) & 2293 & 4506 & 4980 & 11.0 & 10.2 & 10.3 & 10.1 & 10.7 & 10.5 & 6.1 \\
\hline MIROC-CHEM (MI) & $*$ & $*$ & 4805 & 13.4 & 12.4 & 12.4 & $*$ & $*$ & 8.7 & 5.1 \\
\hline MOCAGE (MO) & 2126 & 4205 & 4678 & 11.6 & 12.5 & 13.3 & 8.2 & 7.5 & 7.1 & 4.1 \\
\hline NCAR-CAM3.5 (NC) & 2209 & 4309 & 4903 & 10.7 & 11.3 & 12.0 & 10.7 & 9.9 & 9.2 & 5.4 \\
\hline STOC-HadAM3 (ST) & 2127 & 4161 & 4708 & 11.8 & 11.6 & 12.1 & 9.7 & 9.6 & 9.1 & 5.3 \\
\hline TM5 (TM) & 2173 & $*$ & 4820 & 10.9 & $*$ & 10.5 & 9.8 & $*$ & 9.9 & 5.8 \\
\hline UM-CAM (UM) & 2209 & 4323 & 4879 & 7.0 & 7.1 & 7.4 & 15.0 & 14.7 & 14.0 & 8.4 \\
\hline $\mathrm{MMM} \pm \mathrm{STD}$ & $2179 \pm 47$ & $4290 \pm 115$ & $4813 \pm 81$ & $11.3 \pm 1.7$ & $10.8 \pm 1.6$ & $11.1 \pm 1.6$ & $10.1 \pm 1.7$ & $10.2 \pm 1.7$ & $9.7 \pm 1.5$ & $5.7 \pm 0.9$ \\
\hline $\mathrm{CV}(\%)$ & 2.2 & 2.7 & 1.7 & 15.2 & 14.8 & 14.6 & 17.3 & 16.4 & 15.6 & 16.3 \\
\hline $\begin{array}{l}\text { Observation-derived estimates } \\
\text { (Prinn et al., 2005; } \\
\text { Prather et al., 2012) }\end{array}$ & & & & & & & & & $\begin{array}{l}10.2_{-0.7}^{+0.9} \\
11.2 \pm 1.3\end{array}$ & $\begin{array}{l}6.0_{-0.4}^{+0.5} \\
6.3 \pm 0.4\end{array}$ \\
\hline
\end{tabular}

Of the 17 models, 10 models performed an additional simulation (Em2000C11850) with emissions fixed at 2000 levels, but with climate (SSTs and SIC) set to 1850 conditions (wellmixed greenhouse gases, including methane and ozone depleting substances (ODSs) were also set to 1850 levels for radiation calculations). The difference of Em2000Cl1850 from the 2000 simulation allows us to investigate the influence of historical climate change on global $\mathrm{OH}$ and the methane lifetime. Furthermore, a few of these models performed a series of attribution experiments, specifically designed to ascribe ozone and $\mathrm{OH}$ changes to the increases in anthropogenic emissions of individual species $\left(\mathrm{NO}_{\mathrm{x}}, \mathrm{CO}, \mathrm{NMVOCs}\right)$ and to the rise in methane concentrations (Stevenson et al., 2013).

\subsection{Analysis approach}

We calculate the tropospheric methane lifetime against loss by $\mathrm{OH}\left(\tau_{\mathrm{CH}_{4}}\right)$ as the ratio of the global atmospheric methane burden $\left(\mathrm{B}_{\mathrm{CH}_{4}}\right)$ and the global annual mean tropospheric methane-OH oxidation flux $\left(\mathrm{L}_{\mathrm{CH}_{4}}\right)$ provided by each model for each year and then averaged over the number of years for each time-slice. Hereafter, "methane lifetime" refers to the lifetime against loss by tropospheric $\mathrm{OH}\left(\tau_{\mathrm{CH}_{4}}\right)$. The total methane lifetime additionally includes the small stratospheric and soil sinks (Prather et al., 2001; Stevenson et al., 2006; Voulgarakis et al., 2013). For tropospheric global budgets, we define the troposphere to extend from the surface to a fixed pressure level of $200 \mathrm{hPa}$ on each model's native verti- cal grid. We calculated methane lifetime with the tropopause defined as air with ozone concentrations less than or equal to $150 \mathrm{ppbv}$ in the 1850 time-slice simulation (Stevenson et al., 2006; Young et al., 2013) (Table S3 in Supplement) and found it to be within $1 \%$ of the values obtained with the tropopause at $200 \mathrm{hPa}$ (Table 1). Thus we conclude that the definition of the tropopause has minimal effect on the calculated methane lifetime. With the exception of global budget terms, we weight global mean quantities reported here by the mass of air in each model grid cell.

We also calculate the tropospheric lifetime of $\mathrm{CH}_{3} \mathrm{CCl}_{3}$ against $\mathrm{OH}$ loss $\left(\tau_{\mathrm{CH}_{3} \mathrm{CCl}_{3}}\right)$ as a means of testing model simulated global mean tropospheric $\mathrm{OH}$ concentrations for present-day. Since models did not simulate the chemistry and distribution of $\mathrm{CH}_{3} \mathrm{CCl}_{3}$, we calculate its tropospheric lifetime by scaling the methane lifetime with the ratio of the rate coefficient of the reactions of methane and $\mathrm{CH}_{3} \mathrm{CCl}_{3}$ with $\mathrm{OH}$ (Prather and Spivakovsky, 1990) integrated from the surface to the tropopause as $\tau_{\mathrm{CH}_{3} \mathrm{CCl}_{3}}=\tau_{\mathrm{CH}_{4}} \frac{\int_{\mathrm{scc}}^{\text {trop }} k_{\mathrm{CH}_{4}+\mathrm{OH}}(T)}{\int_{\mathrm{sfc}}^{\mathrm{trop}} k_{\mathrm{CH}_{3} \mathrm{CCl}_{3}+\mathrm{OH}(T)}}$, where $k_{\mathrm{CH}_{3} \mathrm{CCl}_{3}+\mathrm{OH}}(T)$, the temperature-dependent rate coefficient for the oxidation of $\mathrm{CH}_{3} \mathrm{CCl}_{3}$ by tropospheric $\mathrm{OH}$ is $1.64 \times 10^{-12} \exp (-1520 / T)$ molec $^{-1} \mathrm{~cm}^{3} \mathrm{~s}^{-1}$ (Sander et al., 2011). We apply monthly mean 3-dimensional temperature as diagnosed by each model to calculate this rate coefficient. The derived tropospheric chemical lifetime of $\mathrm{CH}_{3} \mathrm{CCl}_{3}$ is referred to as " $\mathrm{CH}_{3} \mathrm{CCl}_{3}$ lifetime" here and does not include 
Table 2. Inter-hemispheric ratio (N/S) of tropospheric mean $\mathrm{OH}$ from models for 1850, 1980 and 2000 time-slices. Observationderived estimates shown in the last row are based on Montzka et al. (2001), Prinn et al. (2001), Krol and Lelieveld (2003), and Bousquet et al. (2005). A cell with * means that the model did not report that quantity

\begin{tabular}{llll}
\hline & \multicolumn{3}{c}{ N/S Ratio } \\
\hline Models & 1850 & 1980 & 2000 \\
CESM-CAM-superfast & 1.26 & 1.40 & 1.42 \\
CICERO-OsloCTM2 & 1.22 & 1.36 & 1.42 \\
CMAM & 1.08 & 1.16 & 1.20 \\
EMAC & 1.06 & 1.11 & 1.13 \\
GEOSCCM & 1.07 & 1.12 & 1.18 \\
GFDL-AM3 & 1.07 & 1.16 & 1.20 \\
GISS-E2-R & 1.01 & 1.30 & 1.23 \\
GISS-E2-R-TOMAS & 1.02 & 1.13 & 1.13 \\
HadGEM2 & 1.11 & 1.29 & 1.34 \\
LMDzORINCA & 1.13 & 1.22 & 1.24 \\
MIROC-CHEM & 1.20 & 1.27 & 1.29 \\
MOCAGE & 1.03 & 1.28 & 1.32 \\
NCAR-CAM3.5 & 1.29 & 1.36 & 1.39 \\
STOC-HadAM3 & 1.14 & 1.26 & 1.31 \\
TM5 & 1.14 & $*$ & 1.28 \\
UM-CAM & 1.21 & 1.34 & 1.40 \\
MMM \pm STD & $1.13 \pm 0.09$ & $1.25 \pm 0.10$ & $1.28 \pm 0.10$ \\
CV (\%) & 7.7 & 7.7 & 7.6 \\
\hline Observation-derived & & & $0.85-0.98$ \\
estimates & & & \\
\hline
\end{tabular}

the small stratospheric and oceanic losses (Prinn et al., 2005; Prather et al., 2012).

\section{Historical $\mathrm{OH}$ and methane lifetime}

Table 1 shows annual mean global total methane burden, tropospheric mean $\mathrm{OH}$ and methane lifetime from the 16 global models for the 1850, 1980 and 2000 time-slices. The global methane burden increases by more than a factor of two from 1850 to 2000 in all models. Simulated methane abundances are not sensitive to how methane was prescribed in the models (Lamarque et al., 2013). Despite similar imposed changes in emissions, specifically increases in the emissions of $\mathrm{NO}_{\mathrm{x}}$ (contributing to secondary $\mathrm{OH}$ production), CO and NMVOCs (OH sinks) (Young et al., 2013), and in the methane burden over the 1850 to 2000 period, the models simulate different change in $\mathrm{OH}$ ranging from an increase to a decrease. All models simulate larger increases or smaller decreases in tropospheric $\mathrm{OH}$ abundance in the Northern Hemisphere (NH) compared to the Southern Hemisphere (SH) consistently from 1850 to 2000 (Table 2). We explore the changes in $\mathrm{OH}$, methane lifetime and their driving factors for present-day relative to preindustrial and to $1980 \mathrm{in}$ Sects. 4 and 5, respectively, in an attempt to identify the key processes responsible for the different simulated $\mathrm{OH}$ trends.

\subsection{Evaluation of present-day $\mathrm{OH}$}

Comparison between modeled and observed $\mathrm{OH}$ concentrations provides insight into the budget of $\mathrm{OH}$ and an understanding of the underlying chemistry (e.g. Stone et al., 2012 and references therein). A thorough evaluation of models against direct $\mathrm{OH}$ measurements (ground-based, aircraft) is not particularly useful for constraining global mean $\mathrm{OH}$ because of the enormous temporal and spatial variability in $\mathrm{OH}$ concentrations. Since our simulations represent average climatological conditions, we focus our evaluation on some of the factors controlling $\mathrm{OH}$ distributions at regional and global scales.

Lifetimes of methane and $\mathrm{CH}_{3} \mathrm{CCl}_{3}$ against reaction with tropospheric $\mathrm{OH}$ provide the best constraints on the global mean tropospheric $\mathrm{OH}$ concentration. We compare presentday (2000) methane and $\mathrm{CH}_{3} \mathrm{CCl}_{3}$ lifetimes obtained from models against observationally derived estimates to evaluate the global mean $\mathrm{OH}$ concentrations simulated by the models. The multi-model mean methane lifetime against $\mathrm{OH}$ loss of $9.7 \pm 1.5^{1}$ years (Table 1 ) is about $5 \%$ lower than the mean 1978-2004 tropospheric methane lifetime of $10.2_{-0.7}^{+0.9} \mathrm{yr}$ estimated by Prinn et al. (2005), and is about $13 \%$ lower than the most up-to-date observationally derived estimate of $11.2 \pm 1.3 \mathrm{yr}$ for 2010 (Prather et al., 2012). It is identical to the methane lifetime of $9.7 \pm 1.7 \mathrm{yr}$ obtained from a previous multi-model analysis (Shindell et al., 2006b), and is about 5\% lower than the $10.2 \pm 1.7 \mathrm{yr}$ reported in the recent Hemispheric Transport of Air Pollution (HTAP) multi-model study (Fiore et al., 2009). The variation in methane lifetime across participating models is about the same as that across the previous multi-model estimates (Shindell et al., 2006b; Fiore et al., 2009). Similarly, the multi-model mean $\mathrm{CH}_{3} \mathrm{CCl}_{3}$ lifetime of $5.7 \pm 0.9 \mathrm{yr}$ (Table 1 ), is about $5 \%$ lower than the observationally derived tropospheric lifetime of $6.0_{-0.4}^{+0.5}$ years over the period 19782004 (Prinn et al., 2005), and is about $10 \%$ lower than the recent estimate of $6.3 \pm 0.4$ years (Prather et al., 2012) obtained using $\mathrm{CH}_{3} \mathrm{CCl}_{3}$ observations over the period 19982007 (Montzka et al., 2011). This comparison suggests that the multi-model mean present-day global tropospheric $\mathrm{OH}$ abundance of $11.1 \pm 1.6 \times 10^{5}$ molec $\mathrm{cm}^{-3}$ is overestimated by 5 to $10 \%$ but is within the uncertainty range of observations.

Since the atmospheric oxidizing capacity is sensitive to both the $\mathrm{OH}$ amount and its spatial distribution (Lawrence et al., 2000), we examine the regional $\mathrm{OH}$ distribution in the models as depicted in Fig. 1a showing the multi-model mean $\mathrm{OH}$ concentrations in the different atmospheric sub-domains for the 2000 time-slice (individual models are shown in Fig. S1 in the Supplement). Consistent with previous studies,

\footnotetext{
${ }^{1}$ Slightly different from that reported by Voulgarakis et al. (2013) as we have included results from GISS-E2-R-TOMAS and TM5.
} 

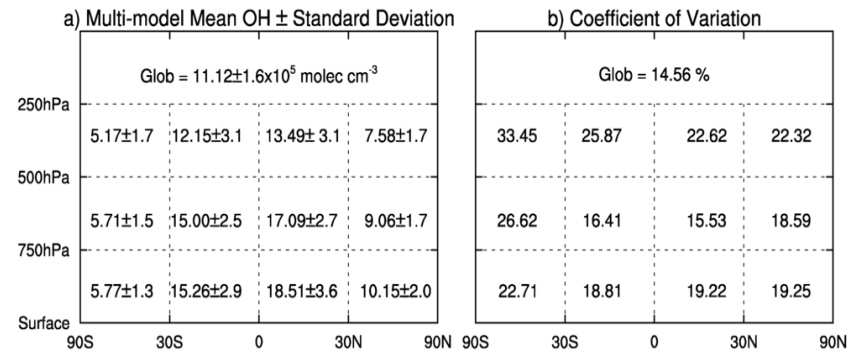

Fig. 1. (a) Multi-model mean regional annual mean airmassweighted $\mathrm{OH}$ concentrations $\left(\times 10^{5}\right.$ molecule $\left.\mathrm{cm}^{-3}\right)$ and (b) the coefficient of variation $(\mathrm{CV}$; standard deviation as percentage of the multi-model mean) for 2000 in the atmospheric subdomains recommended by Lawrence et al. (2001). Global mean tropospheric $\mathrm{OH}$ concentration and $\mathrm{CV}$ are shown in the topmost row of each plot.

the greatest $\mathrm{OH}$ concentrations are found in the tropical troposphere reflecting the abundant sunlight and water vapor (Fig 1a). The individual model biases in tropical specific humidity compared with reanalysis and satellite measurements (Lamarque et al., 2013) are generally consistent with $\mathrm{OH}$ concentrations in the tropical troposphere, i.e., models with high water vapor biases simulate high $\mathrm{OH}$ (compare Figs. S1 with S4 of Lamarque et al., 2013). The NH extratropical troposphere is characterized by higher $\mathrm{OH}$ concentrations than that in the $\mathrm{SH}$ extra-tropics reflecting the influence of higher ozone and $\mathrm{NO}_{\mathrm{x}}$ emissions. A comparison of present-day model tropospheric ozone concentrations against ozonesonde and satellite data indicates that models may have a systematic high bias in the extratropical $\mathrm{NH}$ (Young et al., 2013) perhaps contributing to the high NH extratropical $\mathrm{OH}$. The larger model overestimate of the total column ozone (mainly reflecting stratospheric ozone column) relative to satellite measurements from the merged Total Ozone Mapping Spectrometer/solar backscatter ultraviolet (TOMS/SBUV) data averaged over the 1996-2005 time period (Fig. S2) in the SH than in the NH may also contribute to lower simulated $\mathrm{OH}$ concentrations in the extratropical SH.

Overall, there is large model-to-model variability in the regional distribution of $\mathrm{OH}$. There is, however, less intermodel diversity in the mid-troposphere $\mathrm{OH}$ concentrations compared with those in the lower and upper troposphere (Fig. 1b), except in the SH troposphere where the large intermodel variation possibly reflects diversity in the simulated stratospheric ozone columns and differences in how these influence photolysis in the models. Clouds have also been shown to influence the regional distribution of $\mathrm{OH}$ via photolysis (Liu et al., 2006; Voulgarakis et al., 2009). Evaluation of parent climate models of many of the ACCMIP models against "A-Train" satellite observations indicates that water vapor and clouds are simulated better in the lower and middle troposphere than in the upper troposphere (Jiang et al., 2012) - a factor possibly contributing to the large uncer- tainty in upper tropospheric $\mathrm{OH}$ concentrations. An exhaustive evaluation of the regional distributions of $\mathrm{OH}$ requires more process-level information from the models (e.g. $\mathrm{OH}$ production and loss fluxes, and cloud properties) and should be a priority for future model inter-comparisons.

The present-day multi-model mean $\mathrm{OH}$ inter-hemispheric $(\mathrm{N} / \mathrm{S})$ ratio is $1.28 \pm 0.1$ (Table 2), in contrast to the range of $\mathrm{N} / \mathrm{S}$ values derived from measurements of $\mathrm{CH}_{3} \mathrm{CCl}_{3}$ encompassing the 1980 to 2000 period (Montzka et al., 2000; Prinn et al., 2001; Krol and Lelieveld, 2003; Bousquet et al., 2005). For example, with $\mathrm{CH}_{3} \mathrm{CCl}_{3}$ measurements for 1998-1999, Montzka et al. (2000) estimate that annual mean $\mathrm{OH}$ concentrations are $15 \pm 10 \%$ higher south of the inter-tropical convergence zone (ITCZ) than north of it, while Prinn et al. (2001) derive annual mean $\mathrm{OH}$ concentrations that are $14 \pm 35 \%$ higher in the SH than the NH over the 1978-2000 time period. These observational estimates of N/S OH ratio are highly uncertain as they rely on the assumption of accurate $\mathrm{CH}_{3} \mathrm{CCl}_{3}$ emission estimates and its atmospheric observations. Nevertheless, model derived N/S inter-hemispheric asymmetry is consistent with present-day tropospheric ozone distributions in the ACCMIP models that are biased high and low in the $\mathrm{NH}$ and $\mathrm{SH}$, respectively, against satellite and ozonesonde observations (Young et al., 2013). The models thus overestimate $\mathrm{OH}$ production from ozone in the $\mathrm{NH}$ relative to $\mathrm{SH}$.

Several factors including model-to-model differences in emissions, particularly natural emissions (since models used similar anthropogenic emissions), underlying chemical mechanisms (that dictate the VOC speciation and emissions), stratospheric ozone column, cloud amounts, photolysis schemes, and interactions with aerosols likely all contribute to the large intermodel variation in the simulated present-day tropospheric $\mathrm{OH}$ concentrations (and methane and $\mathrm{CH}_{3} \mathrm{CCl}_{3}$ lifetimes). For example, lowest tropospheric mean $\mathrm{OH}$ in UM-CAM most likely stems from its offline photolysis scheme that does not account for changes in clouds, overhead ozone column, or aerosols, resulting in very low photolysis rates and $\mathrm{OH}$ (Voulgarakis et al., 2013). The highest tropospheric mean $\mathrm{OH}$ abundances are simulated by the CESM-CAM-superfast and MOCAGE models. The representation of NMVOCs is minimal in CESM-CAMsuperfast model as it includes isoprene only, thus simulating a smaller sink for $\mathrm{OH}$. Even though MOCAGE has the highest NMVOC emissions, thus a bigger OH sink, (Table S1), other factors contribute to its high $\mathrm{OH}$, including the lack of inclusion of aerosol photochemical effects in the model (Bousserez et al., 2007). In addition, low stratospheric ozone columns in MOCAGE may enhance UV radiation resulting in greater $\mathrm{OH}$ production, although we cannot directly diagnose this as photolysis rates are not available from MOCAGE. High NMVOC emissions have also been suggested as a possible reason for high $\mathrm{OH}$ in MOCAGE (Voulgarakis et al., 2013). Availability of key OH diagnostics from all models participating in future multi-model 


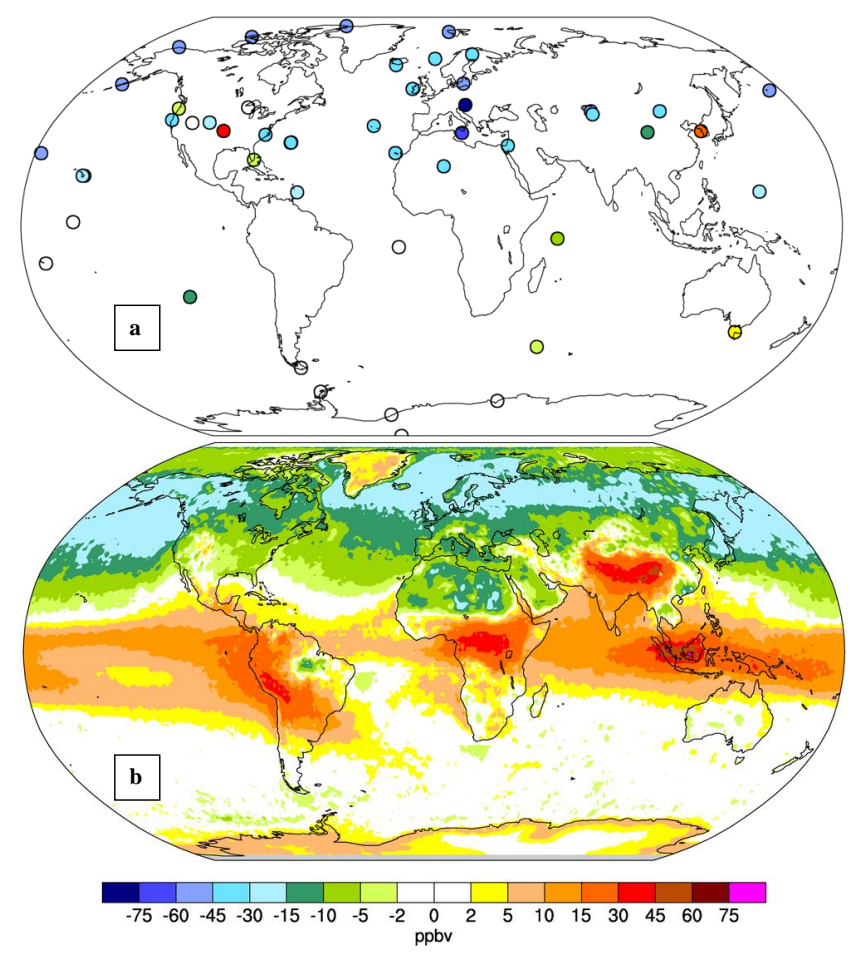

Fig. 2. Annual average bias of multi-model mean $\mathrm{CO}$ for 2000 against (a) surface CO observations averaged over the 1996-2005 period from the NOAA Global Monitoring Division (GMD) network (Novelli and Masarie, 2010; downloaded on April 11, 2012) and (b) average 2000-2006 MOPITT CO at $500 \mathrm{hPa}$. Each circle in (a) indicates the annual mean bias at the $\mathrm{CO}$ measurement site. For comparison with satellite observations in (b), each model was convolved with the MOPITT operator (a priori and averaging kernels) before taking the difference.

intercomparison projects will facilitate a better understanding of inter-model diversity in $\mathrm{OH}$ distributions and contribute to a process-based understanding of the drivers of $\mathrm{OH}$.

\subsection{Comparison of present-day $\mathrm{CO}$ with observations}

CO is the major sink of tropospheric OH (Jacob 1999; Duncan and Logan, 2008), hence, any biases in CO will likely influence the distribution of $\mathrm{OH}$. Here, we evaluate the simulated $\mathrm{CO}$ distributions against surface and satellite measurements to test if $\mathrm{OH}$ sinks may also be too low in the $\mathrm{NH}$ compared with the $\mathrm{SH}$ resulting in higher $\mathrm{NH}-\mathrm{OH}$ concentrations. We compare annual mean $\mathrm{CO}$ from the models with surface CO measurements averaged over the 1996-2005 period from the NOAA Global monitoring Division (GMD) Carbon Cycle Cooperative Global Air Sampling Network (Novelli and Masarie, 2010) for 50 sites (Fig. 2a) and with the observed mean 2000-2006 CO distribution at $500 \mathrm{hPa}$ from the Measurements of Pollution In The Troposphere (MOPITT) instrument (Fig. 2b). For comparison with surface observations, we sampled model results at pressure levels closest to the pressure altitude, latitude and longitude of the observation sites. For comparison with MOPITT CO, we used monthly mean daytime values derived from version 4 (V4) level 3 retrievals from March 2000 to December 2006 provided at a horizontal resolution of $1^{\circ} \times 1^{\circ}$ and at 10 retrieval levels (Deeter et al., 2010). For proper comparison, we transformed each model's $\mathrm{CO}$ by first interpolating it to the MOPITT grid and then applying the averaging kernel and a priori profile associated with each MOPITT retrieval (Shindell et al., 2006b; Emmons et al., 2009). A priori profiles associated with V4 are based on a monthly climatology from the global chemical transport model MOZART-4. Detailed evaluation of MOPITT V4 CO retrievals between 2002 and 2007 with in situ measurements show biases of less than $1 \%$ at the surface, $700 \mathrm{hPa}$ and $100 \mathrm{hPa}$, and a bias of about $-6 \%$ at $400 \mathrm{hPa}$ (Deeter et al., 2010).

The multi-model mean underestimates the observed surface $\mathrm{CO}$ concentrations at most sites in the NH (Fig. 2a), with strong negative biases (up to $60 \mathrm{ppbv}$ ) at many high latitude sites. Negative biases persist at the northern mid-latitude sites albeit with smaller magnitudes than at the northern highlatitude sites. In the $\mathrm{SH}$, the multi-model mean is within \pm 2 ppbv at most sites. Consistent with the surface $\mathrm{CO}$ comparison, the multi-model mean underestimates the MOPITT $\mathrm{CO}$ at $500 \mathrm{hPa}$ throughout the $\mathrm{NH}$, except over northern India and south-central China (Fig. 2b). The overestimate over these South Asian regions is present in all models (Fig. S3) and is particularly dominant in the comparison for September (not shown), indicating excessive transport and/or emissions. The multi-model mean CO reproduces the MOPITT values over much of the $\mathrm{SH}$, except over central Africa, western South America, Indonesia and surrounding Indian and Pacific oceans possibly related to discrepancies in biomass burning emissions (Fig 2b). Despite these regional biases, the models capture the overall spatial distribution of MOPITT $\mathrm{CO}$ fairly well as indicated by the high values of spatial correlation coefficients (Table 3 ).

The multi-model mean $\mathrm{CO}$ concentrations generally agree better with observations in the $\mathrm{SH}$, and are biased low in the $\mathrm{NH}$, similar to the earlier multi-model results of Shindell et al. (2006b). The simulated low CO levels in the NH are consistent with a weaker-than-observed $\mathrm{OH}$ sink that contributes to the larger $\mathrm{OH}$ north-to-south asymmetry compared to that derived from $\mathrm{CH}_{3} \mathrm{CCl}_{3}$ observations.

\section{Preindustrial to present-day changes in $\mathrm{OH}$ and methane lifetime, and their driving factors}

We now explore the changes in $\mathrm{OH}$ from preindustrial to present-day and their driving factors. The multi-model tropospheric mean $\mathrm{OH}$ oxidative capacity has remained nearly constant over the past $150 \mathrm{yr}$ (Table 4). Globally, increases in factors that enhance $\mathrm{OH}$ - humidity $(4.7 \pm 2.6 \%)$, tropospheric ozone ( $38 \pm 10.8 \%$; Young et al., 2013) and $\mathrm{NO}_{\mathrm{x}}$ 
Table 3. Model versus MOPITT CO annual mean bias for the Northern Hemisphere (NH), Southern Hemisphere (SH), and Global at 500 hPa. Annual mean spatial pattern correlation coefficients $(r)$ between model and MOPITT CO global retrievals are in the right-most column.

\begin{tabular}{lrrrr}
\hline & \multicolumn{3}{c}{ Bias (ppbv) } & \\
\cline { 2 - 4 } Models & $\mathrm{NH}$ & $\mathrm{SH}$ & Global & $r$ \\
\hline CESM-CAM-superfast & -31.92 & -17.65 & -24.79 & 0.83 \\
CICERO-OsloCTM2 & 1.56 & 6.99 & 4.28 & 0.86 \\
CMAM & -13.68 & -4.54 & -9.10 & 0.93 \\
EMAC & -1.79 & 2.24 & 0.23 & 0.93 \\
GEOSCCM & -5.73 & 0.00 & -2.86 & 0.87 \\
GFDL-AM3 & -9.01 & 0.58 & -4.22 & 0.89 \\
GISS-E2-R & 19.23 & 25.64 & 22.43 & 0.91 \\
GISS-E2-R-TOMAS & 7.54 & 11.88 & 9.71 & 0.89 \\
HadGEM2 & 3.05 & 6.40 & 4.73 & 0.76 \\
LMDzORINCA & 3.14 & 4.36 & 3.75 & 0.93 \\
MIROC-CHEM & -12.57 & -0.76 & -6.65 & 0.92 \\
MOCAGE & 0.67 & -2.46 & -0.89 & 0.76 \\
NCAR-CAM3.5 & -12.59 & -0.05 & -6.32 & 0.87 \\
STOC-HadAM3 & 7.37 & 11.22 & 9.31 & 0.85 \\
TM5 & -10.27 & -1.33 & -5.80 & 0.86 \\
UM-CAM & 13.24 & 21.27 & 17.26 & 0.89 \\
MMM \pm STD & $-2.6 \pm 12.4$ & $4.0 \pm 10.3$ & $0.7 \pm 11.2$ & $0.87 \pm 0.05$ \\
\hline
\end{tabular}

Table 4. Preindustrial (1850) to present-day (2000) changes in global mean tropospheric $\mathrm{OH}$, tropospheric methane lifetime $\left(\tau_{\mathrm{CH}_{4}}\right)$, $\mathrm{CO}$ and $\mathrm{NO}_{\mathrm{x}}$ burdens, stratospheric ozone column $\left(\right.$ Strat $\left.\mathrm{O}_{3}\right)$, humidity $(\mathrm{Q})$, and temperature $(T)$. Absolute changes in airmass-weighted temperature are given, while the rest of the quantities are expressed as percentage changes relative to 1850 . Models that simulate reductions in present-day $\mathrm{OH}$ relative to preindustrial are shown in bold. A cell with * means that the model did not report that quantity.

\begin{tabular}{lrrrrrrr}
\hline Models & $\Delta \mathrm{OH}(\%)$ & $\Delta \tau_{\mathrm{CH}_{4}}(\%)$ & $\Delta \mathrm{CO}(\%)$ & $\Delta \mathrm{NO}_{\mathrm{x}}(\%)$ & $\Delta \mathrm{Strat}_{3}(\%)$ & $\Delta \mathrm{Q}(\%)$ & $\Delta T(\mathrm{~K})$ \\
\hline CESM-CAM-superfast & 6.1 & -9.8 & 100.3 & 243.8 & -7.6 & 8.1 & 1.4 \\
CICERO-OsloCTM2 & $-\mathbf{1 1 . 1}$ & $\mathbf{9 . 2}$ & $\mathbf{1 1 4 . 3}$ & $\mathbf{8 9 . 8}$ & $\mathbf{0 . 5}$ & $\mathbf{0 . 0}$ & $\mathbf{0 . 0}$ \\
CMAM & $-\mathbf{9 . 6}$ & $\mathbf{8 . 1}$ & $\mathbf{1 1 0 . 9}$ & $\mathbf{5 6 . 3}$ & $-\mathbf{3 . 2}$ & $\mathbf{8 . 3}$ & $\mathbf{1 . 2}$ \\
EMAC & $-\mathbf{7 . 6}$ & $\mathbf{2 . 1}$ & $\mathbf{1 0 2 . 1}$ & $\mathbf{6 3 . 4}$ & $-\mathbf{1 . 2}$ & $\mathbf{5 . 4}$ & $\mathbf{0 . 9}$ \\
GEOSCCM & $-\mathbf{1 2 . 7}$ & $\mathbf{1 2 . 0}$ & $\mathbf{1 2 0 . 3}$ & $\mathbf{6 2 . 5}$ & $-\mathbf{4 . 0}$ & $\mathbf{5 . 7}$ & $\mathbf{1 . 0}$ \\
GFDL-AM3 & $-\mathbf{8 . 1}$ & $\mathbf{5 . 1}$ & $\mathbf{8 6 . 1}$ & $\mathbf{4 1 . 8}$ & $-\mathbf{2 . 4}$ & $\mathbf{3 . 4}$ & $\mathbf{0 . 6}$ \\
GISS-E2-R & 7.0 & -10.6 & 68.9 & 39.5 & -6.1 & 5.8 & 0.9 \\
GISS-E2-R-TOMAS & 9.1 & -11.7 & 71.1 & 33.6 & -6.6 & 7.6 & 1.1 \\
HadGEM2 & $-\mathbf{0 . 7}$ & $-\mathbf{0 . 1}$ & $\mathbf{8 4 . 3}$ & $\mathbf{1 9 2 . 5}$ & $-\mathbf{6 . 0}$ & $\mathbf{3 . 3}$ & $\mathbf{0 . 5}$ \\
LMDzORINCA & $-\mathbf{5 . 9}$ & $\mathbf{4 . 1}$ & $\mathbf{9 4 . 8}$ & $\mathbf{8 7 . 0}$ & $\mathbf{0 . 3}$ & $*$ & $\mathbf{0 . 8}$ \\
MIROC-CHEM & $-\mathbf{7 . 3}$ & $*$ & $\mathbf{1 0 0 . 9}$ & $\mathbf{7 5 . 9}$ & $-\mathbf{3 . 1}$ & $\mathbf{4 . 7}$ & $\mathbf{0 . 8}$ \\
MOCAGE & 14.6 & -13.5 & 58.1 & 286.6 & -19.7 & 5.2 & 0.9 \\
NCAR-CAM3.5 & 11.7 & -14.1 & 66.3 & 114.7 & -3.3 & 6.9 & 1.1 \\
STOC-HadAM3 & 3.2 & -5.7 & 71.1 & 111.0 & -4.0 & 3.5 & 0.6 \\
TM5 & $-\mathbf{4 . 3}$ & $\mathbf{1 . 2}$ & $\mathbf{9 4 . 1}$ & $\mathbf{6 7 . 7}$ & $\mathbf{0 . 6}$ & $\mathbf{0 . 0}$ & $\mathbf{0 . 0}$ \\
UM-CAM & 6.0 & -6.7 & 81.9 & 161.6 & -6.1 & 3.5 & 0.6 \\
MMM \pm STD & $-0.6 \pm 8.8$ & $-2.0 \pm 8.8$ & $89.1 \pm 18.6$ & $108.0 \pm 75.4$ & $-4.5 \pm 4.8$ & $4.7 \pm 2.6$ & $0.8 \pm 0.4$ \\
\hline
\end{tabular}

(as $\left.\mathrm{NO}+\mathrm{NO}_{2}\right)$ burdens $(108.0 \pm 75.4 \%)$, and decreases in stratospheric ozone $(-4.5 \pm 4.8 \%)$, which modulate tropospheric ozone photolysis rates - are compensated by increases in $\mathrm{OH}$ sinks - doubling of methane (Table 1) and CO burdens (Table 4). Tropospheric temperature that controls water vapour abundance and reaction rates also increases $(0.8 \pm 0.4 \mathrm{~K})$ during this period. The near-constant global mean $\mathrm{OH}$ over the historical period is consistent with the findings of Lelieveld et al. (2002, 2004). There is, however, large intermodel spread in the simulated changes in $\mathrm{OH}$, ranging from a decrease of $12.7 \%$ (GEOSCCM) to an increase of $14.6 \%$ (MOCAGE) (Table 4). It is notable that with the consistent ACCMIP modeling specifications, the preindustrial to present-day percent changes in $\mathrm{OH}$ for all ACCMIP models are within $\pm 15 \%$, a range significantly reduced from the previously published model estimates of 
preindustrial to present-day OH changes (Table 1 of John et al., 2012).

We now discuss regional changes in annual mean $\mathrm{OH}$ by relating them to regional changes in chemistry $\left(\mathrm{CO}, \mathrm{NO}_{\mathrm{x}}\right.$ burdens, stratospheric ozone) and climate drivers (humidity and temperature) of $\mathrm{OH}$. Preindustrial to present-day changes in multi-model mean $\mathrm{OH}, \mathrm{CO}$ and $\mathrm{NO}_{\mathrm{x}}$ burdens, humidity and temperature for 12 tropospheric subdomains, as defined by Lawrence et al. (2001), are shown in Fig. 3 (left column). Strong intermodel diversity exists in the magnitude of $\mathrm{NO}_{\mathrm{x}}$ burden changes, particularly in the upper troposphere (Fig. 3e), possibly reflecting the model-to-model differences in processes that dominate the response in this region and the uncertainty associated with lightning $\mathrm{NO}_{\mathrm{x}}$ emissions. The intermodel diversity in $\mathrm{CO}$, humidity and temperature changes is much lower compared to that for $\mathrm{NO}_{\mathrm{x}}$ changes. Strong intermodel variation exists in both the sign and magnitude of regional preindustrial to present-day changes in $\mathrm{OH}$ (see Fig. S4 for regional $\mathrm{OH}$ changes in individual models). For many atmospheric regions, the standard deviation in $\mathrm{OH}$ change across models is greater than the multi-model mean change (Fig. 3a) suggesting that the changes are not statistically significant. The NH lower tropospheric (surface to $750 \mathrm{hPa}$ ) extra-tropics $\left(30^{\circ}-90^{\circ} \mathrm{N}\right)$ is the only region of the atmosphere where the models agree on the sign of $\mathrm{OH}$ change (increase), and its magnitude appears to be statistically significant (multi-model mean greater than standard deviation). This is also the region with the largest increases in $\mathrm{CO}$ and $\mathrm{NO}_{\mathrm{x}}$ burdens (Fig. 3c, e), driven by the changes in anthropogenic emissions which are similar in all the models. Humidity levels increase everywhere (Fig. $3 \mathrm{~g}$ ) in response to temperature increases (Fig. 3i). Strong increases in tropospheric ozone, the primary source of $\mathrm{OH}$, are also simulated in the $\mathrm{NH}$ lower troposphere in response to emission increases (Young et al., 2013). Thus, combined increases in water vapor, ozone and $\mathrm{NO}_{\mathrm{x}}$ outweigh $\mathrm{CO}$ increases resulting in enhanced $\mathrm{OH}$ levels in the $\mathrm{NH}$ extratropical lower troposphere in the present-day relative to preindustrial.

Reflecting the changes in $\mathrm{OH}$, there is a large intermodel variability in the preindustrial to present-day change in methane lifetime (Table 4) with increase of $12 \%$ (GEOSCCM) to decrease of $14.1 \%$ (NCAR-CAM3.5). Changes in methane lifetime for each model are inversely proportional to the $\mathrm{OH}$ change in the model, except for HadGEM2 which shows no change in global mean $\mathrm{OH}$.

\subsection{Diversity in preindustrial to present-day changes}

Here, we explore the diversity in preindustrial to present-day changes in global $\mathrm{OH}$ using the ratio of the change in global mean tropospheric $\mathrm{CO}$ and $\mathrm{NO}_{\mathrm{x}}$ burdens $\left(\Delta \mathrm{CO} / \Delta \mathrm{NO}_{\mathrm{x}}-\right.$ approximately represents changes in $\mathrm{OH}$ sinks versus changes in $\mathrm{OH}$ sources) simulated by the models. Previous studies have found a linear dependence of changes in global mean $\mathrm{OH}$ to the ratio of $\mathrm{CO}$ and hydrocarbon sources and
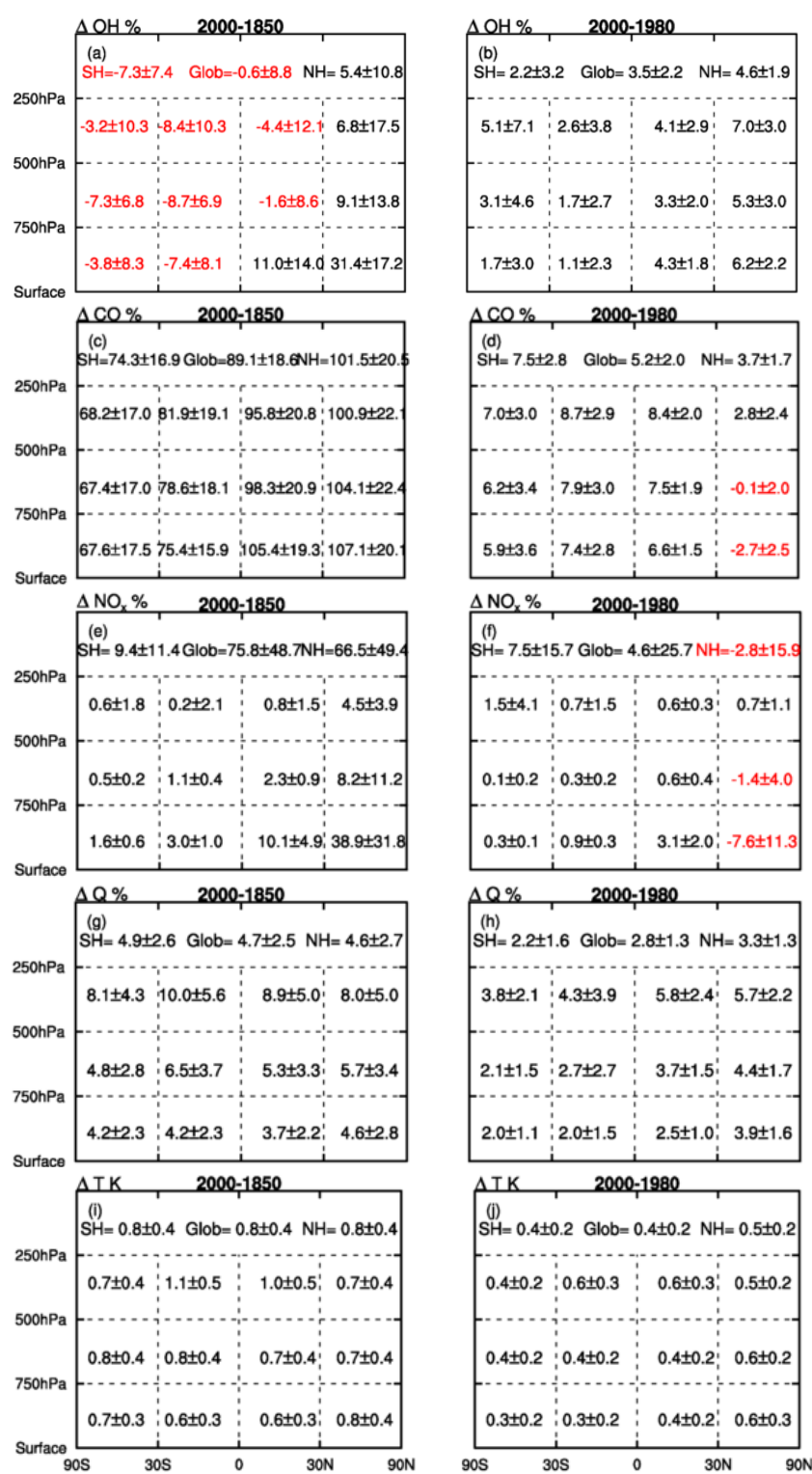

Fig. 3. Multi-model mean percentage change in tropospheric $\mathrm{OH}$, $\mathrm{CO}$ and $\mathrm{NO}_{\mathrm{x}}$ burdens, humidity $(\mathrm{Q})$, and absolute change in temperature for 12 subdomains of the atmosphere as defined by Lawrence et al. (2001) for 2000-1850 (left) and 2000-1980 (right). Decreases are shown in red and increases are in black. Changes in the mean global (Glob), Southern Hemisphere (SH), and Northern Hemisphere (NH) troposphere (surface to $200 \mathrm{hPa}$ ) are shown in the topmost row of each plot.

$\mathrm{NO}_{\mathrm{x}}$ sources (Wang and Jacob, 1998) or to the ratio of CO and $\mathrm{NO}_{\mathrm{x}}$ emissions when changes in VOC emissions are small (Dalsøren and Isaksen, 2006). We find that intermodel variation in the sign and magnitude of the preindustrial to present-day change in global mean $\mathrm{OH}$, whether positive or negative, correlates strongly with $\Delta \mathrm{CO} / \Delta \mathrm{NO}_{\mathrm{x}}$ (Fig. 4; coefficient of determination $\left.\left(r^{2}\right)=0.7\right)$. Models that simulate decreases in present-day global mean $\mathrm{OH}$ relative to 


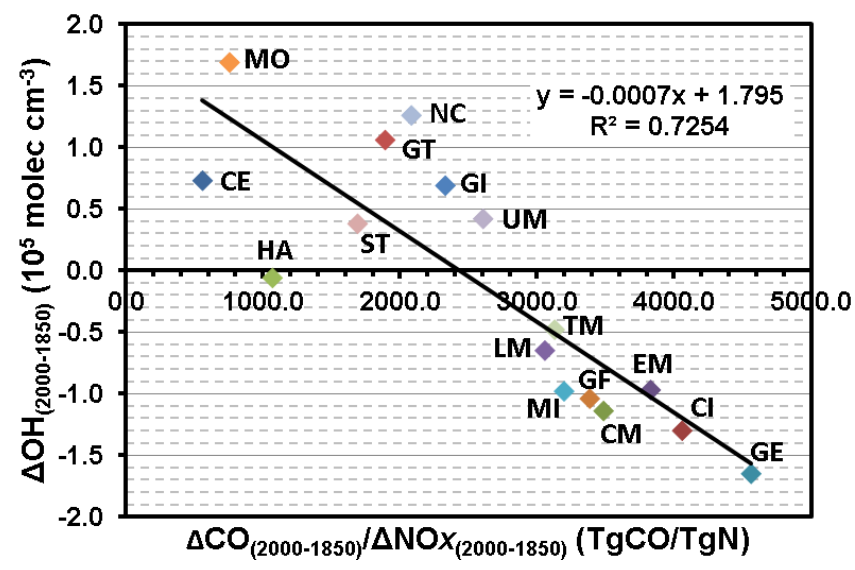

Fig. 4. Scatterplot of absolute change in annual average tropospheric mean $\mathrm{OH}$ concentration from preindustrial (1850) to present-day (2000) versus the ratio of absolute changes in annual average total tropospheric $\mathrm{CO}$ and $\mathrm{NO}_{\mathrm{x}}$ burdens for each of the 16 models. Each model data point is denoted by the first two letters of the model name shown in Table 1. Solid line corresponds to a linear regression of changes in $\mathrm{OH}$ with the ratio of changes in $\mathrm{CO}$ and $\mathrm{NO}_{\mathrm{X}}$ burdens. The regression equation is shown on the upper right corner of the plot.

preindustrial have stronger increases in $\mathrm{OH}$ sinks compared with sources (except HadGEM2), while models that simulate increase in $\mathrm{OH}$ show larger relative increases in sources versus sinks (except GISS-E2-R and GISS-E2-R-TOMAS) (Table 4). Removing the three outlier models increases the $r^{2}$ to 0.8 . The correlation is particularly tight for models that simulate preindustrial to present-day $\mathrm{OH}$ decreases.

This analysis leads to the question of why the preindustrial to present-day changes in global $\mathrm{CO}$ and $\mathrm{NO}_{\mathrm{x}}$ burdens are different across models despite imposing seemingly similar trends in total $\mathrm{CO}$ and $\mathrm{NO}_{\mathrm{x}}$ emissions and methane burdens (Fig. 1 and Table S1 of Young et al., 2013). We attribute the diversity in $\Delta \mathrm{CO} / \Delta \mathrm{NO}_{\mathrm{x}}$ to differences in emissions and chemical schemes implemented in the models. The variation in the simulated preindustrial to present-day methane burden trends is small (Table 1), however there are large differences in the $\mathrm{CO}, \mathrm{NO}_{\mathrm{x}}$ and NMVOC emission trends (Table S4) as implemented in the models that drive differences in $\Delta \mathrm{CO} / \Delta \mathrm{NO}_{\mathrm{x}}$, and therefore, $\mathrm{OH}$. Variation in $\mathrm{CO}$ and $\mathrm{NO}_{\mathrm{x}}$ emissions is due to differences in natural emissions ( $\mathrm{CO}$ from oceans and vegetation; $\mathrm{NO}_{\mathrm{x}}$ from soils and lightning) (Young et al., 2013). Additional spread in CO source strength is due to the complexity of NMVOC chemical mechanism included in the models (Young et al., 2013), since NMVOC oxidation is a major CO source (Holloway et al., 2000; Duncan et al., 2007; Grant et al., 2010). For example, some models with simpler NMVOC chemistry include extra CO emissions to account for missing NMVOCs (see Table A1). Different NMVOC oxidation mechanisms lead to a wide range in both anthropogenic (prescribed mostly from the inventory of Lamarque et al., 2010) and biogenic NMVOC emissions. Additional diversity in biogenic NMVOC emission trends comes from the different ways these (particularly isoprene as it is the dominant biogenic NMVOC) are specified (constant versus climate-sensitive) in the models (Table A1). Furthermore, even if the total emissions were identical across models, differences in the way the physical processes (for example, depositional loss, photolysis) that influence the atmospheric lifetimes of $\mathrm{CO}$ and $\mathrm{NO}_{\mathrm{x}}$ in the models will likely produce differences in their atmospheric distributions and trends. Thus, uncertainties in natural emissions and differences in chemical and physical processes implemented in the models drive the spread in the interplay between $\mathrm{OH}$ sources and sinks (approximated as $\Delta \mathrm{CO} / \Delta \mathrm{NO}_{\mathrm{x}}$ ) resulting in the diversity in preindustrial to present-day $\mathrm{OH}$ changes.

Better constraints on natural emissions and the key physical processes controlling the distribution of $\mathrm{OH}$ sources and sinks will help advance our understanding of the evolution of atmospheric $\mathrm{OH}$. Furthermore, concerted efforts to evaluate tropospheric chemistry mechanisms implemented in the models (Luecken et al., 2008; Emmerson and Evans, 2009; Archibald et al., 2010; Chen et al., 2010; Barkley et al., 2011) will also help to make progress in understanding the diversity in $\mathrm{OH}$ distributions and long-term trends across the current generation of chemistry-climate models.

\section{0 to 2000 changes in $\mathrm{OH}$ and methane lifetime}

We now explore the change in $\mathrm{OH}$ and methane lifetime over the 1980 to 2000 period. Consistent with prior modeling studies (Karlsdóttir and Isaksen, 2000; Dentener et al., 2003; Dalsøren and Isaksen, 2006; Hess and Mahowald, 2009; John et al., 2012; Holmes et al., 2013), the multi-model mean $\mathrm{OH}$ increases slightly from 1980 to 2000 by $3.5 \pm 2.2 \%$ (Table 5). Over this period, increases in $\mathrm{OH}$ sinks, specifically the methane $(12 \pm 1.9 \%)$ and $\mathrm{CO}(5.2 \pm 2.0 \%)$ burdens are slightly outweighed by increases in humidity $(2.8 \pm 1.3 \%)$, $\mathrm{NO}_{\mathrm{x}}$ burdens $(4.3 \pm 12.3 \%)$, and stratospheric ozone loss $(3.1 \pm 2.3 \%)$. In contrast to the disagreement in the sign of OH change for the 1850-2000 period, all models agree on a small $\mathrm{OH}$ increase from 1980 to 2000. The multi-model mean methane lifetime decreases by $4.3 \pm 1.9 \%$ from 1980 to 2000 reflecting the small increase in tropospheric $\mathrm{OH}$ and warming of $0.4 \pm 0.2 \mathrm{~K}$. While the models are consistent with each other, the observational estimates of trends in $\mathrm{OH}$ derived from $\mathrm{CH}_{3} \mathrm{CCl}_{3}$ measurements indicate a $\sim 10 \%$ decrease over a similar period (Prinn et al., 2001; Bousquet et al., 2005). More recent analysis of $\mathrm{CH}_{3} \mathrm{CCl}_{3}$ observations over the 1998-2007 period indicates that global OH is well buffered against perturbations (Montzka et al., 2011) and suggests that the uncertainties in $\mathrm{CH}_{3} \mathrm{CCl}_{3}$ data before 1998 may have led to artificially large $\mathrm{OH}$ trends reported in previous studies. Better constraints on $\mathrm{OH}$ trends are important for 
inferring trends in methane sources (and other species lost by $\mathrm{OH})$ via inverse methods.

Regionally, the $\mathrm{NH}$ shows larger $\mathrm{OH}$ increases $(4.6 \pm 1.9 \%)$ (Fig. 3b) than the SH $(2.2 \pm 3.2 \%)$, the latter being where intermodel variability is large (Fig. S5). The largest increases occur in the NH extratropical troposphere (Fig. 3b), which coincide with increases in humidity (Fig. 3h), and decreases in the $\mathrm{CO}$ burden (Fig. 3f). $\mathrm{NO}_{\mathrm{x}}$ burdens decrease in the extratropical $\mathrm{NH}$ lower troposphere in 2000 relative to 1980 , possibly driven by decreasing North American and European emissions (Lamarque et al., 2010; Granier et al., 2011). The large intermodel diversity in the sign of change in the SH may be related to the extent of stratospheric ozone loss and its influence on photolysis as simulated by the models. Previous studies have identified the stratospheric ozone column through its influence on photolysis as a key driver of trends and variability in tropospheric OH, particularly in the SH (Dentener et al., 2003; Wang et al., 2004). Anecdotally, models that simulate strong stratospheric ozone losses and allow the ozone column to affect photolysis rates simulate stronger $\mathrm{OH}$ increases (e.g., GISS-E2-R and MOCAGE), particularly in the extratropical troposphere. Sensitivity simulations that isolate the role of changes in emissions, overhead ozone column, and meteorology are needed to explain the $\mathrm{OH}$ trends and intermodel diversity over the 1980-2000 period (e.g., Dentener et al., 2003).

\section{Sensitivity of $\mathrm{OH}$ and methane lifetime to climate}

We investigate the influence of climate change on $\mathrm{OH}$ and methane lifetime by analysing the simulations performed by 10 models with 2000 emissions but driven by 1850 s climate (Em2000C11850). We compare the base 2000 time-slice and Em2000Cl1850 simulations to diagnose the impact of climate change from 1850 to 2000.

Preindustrial to present-day climate change causes a multimodel mean global OH increase of $2.1 \pm 2.0 \%$ (Fig. 5) and a methane lifetime decrease of $0.30 \pm 0.24 \mathrm{yr}$ (Table 6). All models, except GFDL-AM3, simulate $\mathrm{OH}$ increases (Fig. 5) and methane lifetime decreases (Table 6) in response to historical climate change. GISS-E2-R produces the strongest methane lifetime decrease, while STOC-HadAM3 produces the strongest methane lifetime decrease per unit temperature increase. Increases in water vapour cause tropospheric $\mathrm{OH}$ increases, particularly in the upper troposphere where the relative increases in humidity (Fig. 6a) are greatest. Warmer temperatures and increased $\mathrm{OH}$ enhance oxidative loss of methane (Fig. 6c), decreasing the methane lifetime by $0.30 \pm 0.24 \mathrm{yr}$ (Table 6 ) and representing a small negative climate feedback, in agreement with prior studies (Stevenson et al., 2000, 2006; Johnson et al., 2001; Voulgarakis et al., 2013).

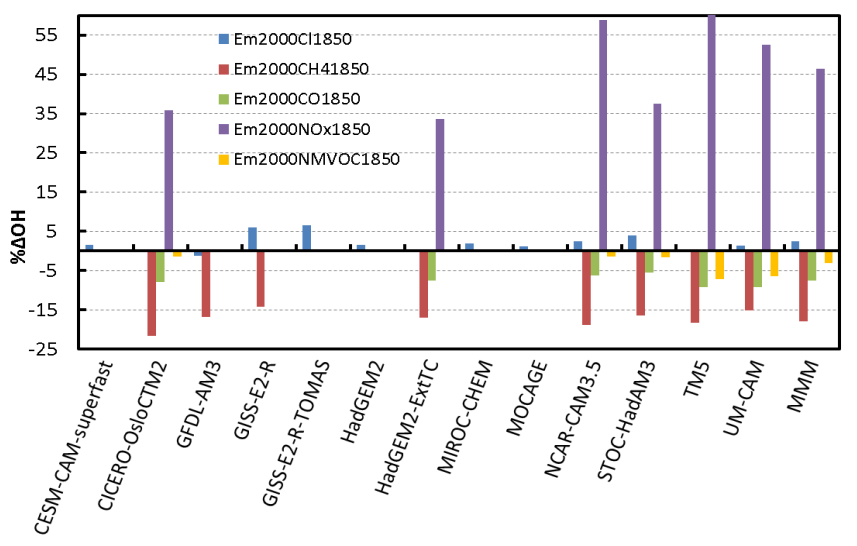

Fig. 5. Percent tropospheric mean $\mathrm{OH}$ concentration change due to preindustrial to present-day changes in climate (Em2000C11850), methane burden (Em2000CH41850), and anthropogenic emissions of $\mathrm{CO}$ (Em2000CO1850), $\mathrm{NO}_{\mathrm{x}}, \quad(\mathrm{Em} 2000 \mathrm{NOx} 1850)$, and NMVOCs (Em2000NMVOC1850). The multi-model mean (MMM) $\mathrm{OH}$ changes for each experiment are also shown.

\section{Attribution of $\mathrm{OH}$ changes to methane burden and $\mathrm{NO}_{\mathrm{x}}, \mathrm{CO}$, and NMVOC emissions}

A subset of the models performed a series of attribution experiments with 2000 climate conditions but with anthropogenic $\mathrm{CO}, \mathrm{NO}_{\mathrm{x}}$ and $\mathrm{NMVOC}$ emissions, and methane concentrations individually set to preindustrial levels. For the methane attribution experiment performed by eight models (Em2000CH41850), the methane concentration was fixed at an 1850s level (791 ppbv), while for the emissions attribution experiments (Em2000CO1850, Em2000NOx1850, and Em2000NMVOC1850) conducted by six models, methane was fixed at a 2000s level (1751 ppbv) and anthropogenic emissions were reduced to their 1850 values separately for each simulation. We subtract results of each perturbation simulation from the base 2000 time-slice simulation to diagnose the impact of preindustrial (1850) to present-day (2000) changes in each of the specific drivers on $\mathrm{OH}$, as shown in Fig. 5. Because methane concentrations were prescribed (rather than using emissions), these attribution simulations are not at steady state with respect to methane concentration and, therefore, OH (Prather, 1994, 1996; Fuglestvedt et al., 1999; Derwent et al., 2001; Wild et al., 2001; Stevenson et al., 2004; Naik et al., 2005; Shindell et al., 2005, 2009; West et al., 2007; Fiore et al., 2008). Here, we only diagnose instantaneous changes in methane lifetime; steady-state changes are addressed by Stevenson et al. (2013).

The largest change in global mean $\mathrm{OH}$ is simulated for preindustrial to present-day increases in anthropogenic $\mathrm{NO}_{\mathrm{x}}$ emissions, followed by increases in methane concentrations, while smaller changes result from increases in $\mathrm{CO}$ and NMVOCs emissions across the subset of models (Fig. 5). Global mean $\mathrm{OH}$ increases by $46.4 \pm 12.2 \%$ due to $\mathrm{NO}_{\mathrm{x}}$ 
Table 5. Same as in Table 4 but for changes in present-day (2000) relative to 1980.

\begin{tabular}{lrrrrrrr}
\hline Models & $\Delta \mathrm{OH}(\%)$ & $\Delta \tau_{\mathrm{CH}_{4}}(\%)$ & $\Delta \mathrm{CO}(\%)$ & $\Delta \mathrm{NO}_{\mathrm{x}}(\%)$ & $\Delta \mathrm{Strat}_{3}(\%)$ & $\Delta \mathrm{Q}(\%)$ & $\Delta T(\mathrm{~K})$ \\
\hline CESM-CAM-superfast & 3.9 & -5.0 & 5.3 & -15.3 & -3.7 & 3.7 & 0.6 \\
CICERO-OsloCTM2 & 0.9 & -1.3 & 6.2 & 3.5 & 0.1 & 0.0 & 0.0 \\
CMAM & 1.7 & -2.8 & 7.9 & 0.4 & -1.5 & 4.2 & 0.6 \\
EMAC & 3.8 & -4.6 & 5.2 & 2.9 & -1.4 & 3.9 & 0.6 \\
GEOSCCM & 0.6 & -1.5 & 8.4 & 1.7 & -2.7 & 2.8 & 0.5 \\
GFDL-AM3 & 2.5 & -3.6 & 5.5 & 3.6 & -4.7 & 3.2 & 0.5 \\
GISS-E2-R & 6.9 & -6.7 & 3.6 & 41.4 & -6.4 & 2.7 & 0.4 \\
GISS-E2-R-TOMAS & 5.9 & -6.7 & 3.5 & 14.3 & -3.5 & 3.6 & 0.6 \\
HadGEM2 & 3.8 & -4.1 & 5.8 & -1.2 & -2.3 & 3.1 & 0.5 \\
LMDzORINCA & 1.4 & -1.8 & 7.1 & 8.3 & 0.1 & $* * *$ & 0.4 \\
MIROC-CHEM & 0.1 & $* .3$ & 7.3 & 5.2 & -2.4 & 0.1 & 0.0 \\
MOCAGE & 6.3 & -5.9 & 1.3 & -7.6 & -8.7 & 2.0 & 0.3 \\
NCAR-CAM3.5 & 5.9 & -6.7 & 3.2 & 4.8 & -2.0 & 4.1 & 0.7 \\
STOC-HadAM3 & 4.4 & -4.6 & 4.1 & -2.2 & -3.4 & 2.7 & 0.4 \\
UM-CAM & 4.8 & -5.2 & 4.0 & 4.1 & -3.6 & 2.7 & 0.5 \\
MMM \pm STD & $3.5 \pm 2.2$ & $-4.3 \pm 1.9$ & $5.2 \pm 2.0$ & $4.3 \pm 12.3$ & $-3.1 \pm 2.3$ & $2.8 \pm 1.3$ & $0.4 \pm 0.2$ \\
\hline
\end{tabular}

Table 6. Change in tropospheric methane lifetime $\left(\tau_{\mathrm{CH}_{4}}\right)$ due to climate change: difference between base 2000 time-slice and a simulation with 1850 climate $(\mathrm{Em} 2000 \mathrm{Cl1850})$. Change in tropospheric temperature $(\Delta T)$ and lifetime change per unit change in temperature $\left(\Delta \tau_{\mathrm{CH}_{4}} / \Delta T\right)$ are also shown for 10 models.

\begin{tabular}{lrrr}
\hline Models & $\Delta \tau_{\mathrm{CH}_{4}}$ (years) & $\Delta T(\mathrm{~K})$ & $\Delta \tau_{\mathrm{CH}_{4}} / \Delta T\left(\mathrm{yr} \mathrm{K}^{-1}\right)$ \\
\hline CESM-CAM-superfast & -0.27 & 1.4 & -0.20 \\
GFDL-AM3 & 0.12 & 0.6 & 0.21 \\
GIS-E2-R & -0.76 & $1.1^{*}$ & -0.69 \\
GISS-E2-R-TOMAS & -0.70 & 1.1 & -0.64 \\
HadGEM2 & -0.20 & 0.5 & -0.40 \\
MIROC-CHEM & -0.25 & 0.8 & -0.30 \\
MOCAGE & -0.20 & 0.9 & -0.23 \\
NCAR-CAM3.5 & -0.37 & 1.1 & -0.34 \\
STOC-HadAM3 & -0.46 & 0.6 & -0.71 \\
UM-CAM & -0.34 & 0.6 & -0.55 \\
MMM \pm STD & $-0.30 \pm 0.24$ & $0.9 \pm 0.3$ & $-0.39 \pm 0.28$ \\
\hline
\end{tabular}

* Temperature change is slightly different from that reported in Table 4 as a different base simulation was used to compare the Em2000Cl1850 simulation.

emission increases as a result of increases in both primary and secondary $\mathrm{OH}$ production. The more than a factor of two increases in methane concentrations at present-day $\mathrm{NO}_{\mathrm{x}}$ levels leads to increases in tropospheric ozone, the primary source of $\mathrm{OH}$. However, $\mathrm{OH}$ is consumed during the oxidation of methane and its oxidation products, so that the net result is a global $\mathrm{OH}$ decrease of $17.3 \pm 2.3 \%$. Smaller decreases in mean $\mathrm{OH}$ occur in response to anthropogenic $\mathrm{CO}$ $(7.6 \pm 1.5 \%)$ and NMVOC emission $(3.1 \pm 3.0 \%)$ increases (Fig. 7). Despite being the major OH sink, the decrease in $\mathrm{OH}$ from $\mathrm{CO}$ increase is smaller than that from methane increase because of the lack of additional oxidation products that can further consume $\mathrm{OH}$.

Methane lifetime also responds most strongly to increases in $\mathrm{NO}_{\mathrm{x}}$, followed by methane, $\mathrm{CO}$ and NMVOC, respectively. However, the response in the perturbation lifetime is different when the nonlinear feedback of methane on its own lifetime is considered (Stevenson et al., 2013). Furthermore, the sum of $\mathrm{OH}$ or methane lifetime changes diagnosed from the individual attribution experiments performed by a model is not equal to the total preindustrial to presentday diagnosed from the historical time-slice simulations (Table 4). This is partly because of the inherent nonlinear chemical system and partly because all the offsetting processes influencing $\mathrm{OH}$ in the coupled chemistry-climate system are not included in these attribution experiments.

Regionally, $\mathrm{OH}$ reductions are slightly stronger in the $\mathrm{SH}$ compared with the $\mathrm{NH}$ in response to methane changes (Fig. 7a) since methane is a more important $\mathrm{OH}$ sink in the SH than in NH (Spivakovsky et al., 2000). On the other 


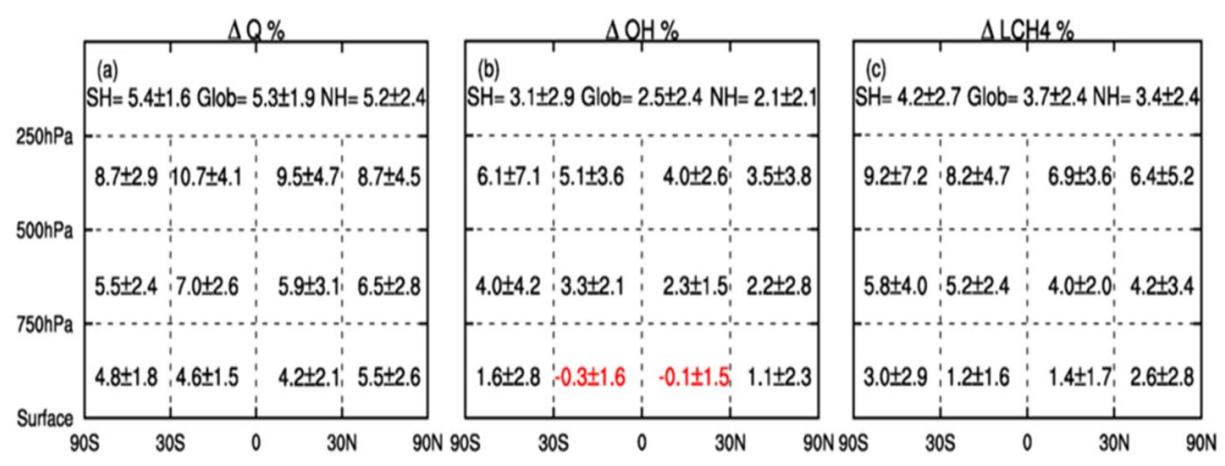

Fig. 6. Percent change in multi-model mean (10 models) regional a) specific humidity, b) tropospheric $\mathrm{OH}$ and c) methane loss flux due to climate change only (2000-Em2000C11850). Decreases are shown in red and increases are in black.

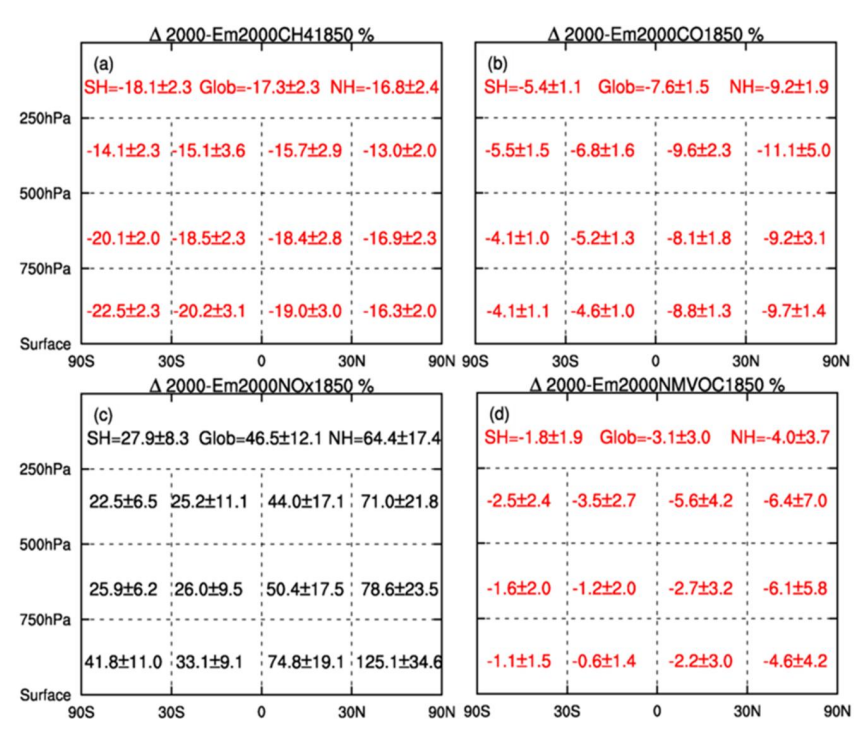

Fig. 7. Percent change in multi-model mean $\mathrm{OH}$ in 12 subdomains of the atmosphere for 2000 relative to attribution experiments: a) Em2000CH41850 (8 models), b) Em2000CO1850 (6 models), c) Em2000NOx1850 (6 models), d) Em2000NMVOC1850 (6 models). $\mathrm{OH}$ increases are shown in black and decreases are in red.

hand, $\mathrm{OH}$ decreases are stronger in the $\mathrm{NH}$ compared with SH for CO and NMVOC emission increases (Fig. 7b, d), reflecting higher anthropogenic sources in the $\mathrm{NH}$ and shorter lifetimes. Increases in anthropogenic $\mathrm{NO}_{\mathrm{x}}$ emissions produce the largest inter-hemispheric asymmetry in the $\mathrm{OH}$ response (Fig. 7c).

Intermodel diversity in the response of $\mathrm{OH}$ to methane and $\mathrm{CO}$ perturbations is small, compared with that for NMVOC and $\mathrm{NO}_{\mathrm{x}}$ perturbations (Fig. 7). Significant diversity in the sign and magnitude of $\mathrm{OH}$ change for different tropospheric regions due to NMVOC emissions (Fig. 7d) reflect the differences in chemistry mechanisms implemented in the models and uncertainties in natural emissions. The chemical mechanisms to represent NMVOC degradation included in models are highly uncertain and better constraints are needed
(Archibald et al., 2010; Barkley et al., 2011). The response of $\mathrm{OH}$ to NMVOCs, particularly biogenic NMVOCs, is an area of active research as several proposed oxidation mechanisms implemented in global chemistry-climate models have yet to satisfactorily explain the model underestimate of $\mathrm{OH}$ concentrations observed over dense tropical forests in low- $\mathrm{NO}_{\mathrm{x}}$ conditions (e.g., Butler et al., 2008; Lelieveld et al., 2008; Hofzumahaus et al., 2009; Peeters et al., 2009; Paulot et al., 2009; Stavrakou et al., 2010; Whalley et al., 2011; Barkley et al., 2011). Efforts that combine observations and modeling activities can help reduce uncertainties in our understanding of the response of $\mathrm{OH}$ to individual driving factors.

\section{Conclusions}

We have investigated the changes in global hydroxyl $(\mathrm{OH})$ radical and methane lifetime in the present-day (2000) relative to preindustrial (1850) and to 1980 by analysing results from 17 global chemistry-climate models. We determined a multi-model mean present-day tropospheric methane lifetime of $9.7 \pm 1.5 \mathrm{yr}$, which is 5 to $13 \%$ lower than recently published observational estimates (Prinn et al., 2005; Prather et al., 2012). Our estimated mean present-day tropospheric methyl chloroform $\left(\mathrm{CH}_{3} \mathrm{CCl}_{3}\right)$ lifetime of $5.7 \pm 0.9 \mathrm{yr}$ is also about 5 to $10 \%$ lower than recent observationally derived estimates (Prinn et al., 2005; Prather et al., 2012). Both the lower methane and methyl chloroform lifetimes suggest that the multi-model tropospheric mean $\mathrm{OH}$ is slightly overestimated but is within the uncertainty range of observations. There is large intermodel variability in the regional distribution of $\mathrm{OH}$ although the models consistently simulate higher $\mathrm{OH}$ concentrations in the Northern Hemisphere (NH) than in the Southern Hemisphere (SH). The models likely overestimate $\mathrm{OH}$ abundances in the $\mathrm{NH}$ versus $\mathrm{SH}$, as suggested by lower simulated $\mathrm{CO}$ concentrations and higher ozone concentrations (Young et al., 2013) in the NH compared with observations.

We calculated the change in $\mathrm{OH}$ and methane lifetime for present-day relative to preindustrial and to 1980 to gain 
a better understanding of their long-term changes. Globally, we find that concurrent increases in factors that enhance $\mathrm{OH}$ (humidity, tropospheric ozone, and $\mathrm{NO}_{\mathrm{x}}$ emissions), together with decreases in stratospheric ozone and increase in tropospheric temperature, have been compensated by increases in $\mathrm{OH}$ sinks (methane concentration, $\mathrm{CO}$ and NMVOC emissions). The net result is a nearly constant global mean $\mathrm{OH}$ concentration over the past $150 \mathrm{yr}$, despite large regional changes, consistent with previous studies (Lelieveld et al., 2002, 2004). Over the same time period, the tropospheric methane lifetime against loss by $\mathrm{OH}$ has decreased slightly $(-2.0 \pm 8.8 \%)$, possibly resulting from a warming-induced increase in its chemical loss. For the 1980 to 2000 period, we find that global mean $\mathrm{OH}$ has increased only slightly $(3.5 \pm 2.2 \%)$ and methane lifetime has decreased by about $4.3 \pm 1.9 \%$ in response to this small $\mathrm{OH}$ increase and climate warming $(0.4 \pm 0.2 \mathrm{~K})$. The multi-model mean OH change for 1980-2000 disagrees with previous work based on $\mathrm{CH}_{3} \mathrm{CCl}_{3}$ observations, which suggest a reduction in $\mathrm{OH}$ in 2000 relative to 1980 (Prinn et al., 2001; Bousquet et al., 2005), but agrees well with other modeling studies (Karlsdóttir and Isaksen, 2000; Dentener et al., 2003; Dalsøren and Isaksen, 2006; Hess and Mahowald, 2009; John et al., 2012; Holmes et al., 2013) as well as a recent study of $\mathrm{OH}$ variability inferred from $\mathrm{CH}_{3} \mathrm{CCl}_{3}$ observations (Montzka et al., 2011).

Substantial intermodel diversity exists in the calculated trends (sign and magnitude) in $\mathrm{OH}$ and methane lifetimes for the preindustrial to present-day change, stemming from the differences in the representation of chemical and physical processes that influence $\mathrm{OH}$ within each model. Particularly, we find that the preindustrial to present-day $\mathrm{OH}$ trend simulated by a model depends linearly on the ratio of the change in global mean tropospheric $\mathrm{CO}$ and $\mathrm{NO}_{\mathrm{x}}$ burdens $\left(\triangle \mathrm{CO} / \Delta \mathrm{NO}_{\mathrm{x}}-\right.$ approximately represents changes in $\mathrm{OH}$ sinks versus changes in $\mathrm{OH}$ sources). With a few exceptions, models with high $\Delta \mathrm{CO} / \Delta \mathrm{NO}_{\mathrm{x}}$ predict $\mathrm{OH}$ decreases while those with lower values simulate $\mathrm{OH}$ increases from preindustrial to present day (Fig. 4). The intermodel diversity in $\Delta \mathrm{CO} / \Delta \mathrm{NO}_{\mathrm{x}}$ reflects the diversity in the chemical mechanisms as well as uncertainties in natural $\mathrm{CO}, \mathrm{NO}_{\mathrm{x}}$ and NMVOC emissions implemented in the models. There is, thus, a need for better constraints on natural precursor emissions and on the chemical mechanisms in the current generation of chemistry-climate models. Further, model-tomodel differences in stratospheric ozone columns, photolysis schemes, clouds, and interactions with aerosols likely all contribute to the inter-model variability in simulated $\mathrm{OH}$ trends. The extent to which each of these factors drives change in global $\mathrm{OH}$ in the different models can be ascertained with well-coordinated process-oriented evaluation of chemistry-climate models.

Using a subset of the models, we further explored the sensitivity of $\mathrm{OH}$ and methane lifetime to historical climate change. We find that preindustrial to present-day climate change has increased global mean $\mathrm{OH}$ by $2.1 \pm 2.0 \%$ and has decreased the methane lifetime by $0.30 \pm 0.24$ years, representing a small negative feedback on the climate system. We further attribute preindustrial to present-day $\mathrm{OH}$ changes to individual increases in methane burden, and anthropogenic emissions of $\mathrm{CO}, \mathrm{NO}_{\mathrm{x}}$, and NMVOCs employing additional perturbations simulations from a few models. With fixed methane burden, we find that $\mathrm{NO}_{\mathrm{x}}$ emissions increase $\mathrm{OH}$ by $46.4 \pm 12.2 \%$, while methane, $\mathrm{CO}$ and NMVOCs decrease OH by $17.3 \pm 2.3 \%, 7.6 \pm 1.5 \%$, and $3.1 \pm 3.0 \%$, respectively. The response of $\mathrm{OH}$ and methane lifetime to emission perturbations would be somewhat different if we had allowed methane abundances to respond to these perturbations, lessening the response to $\mathrm{NO}_{\mathrm{x}}$ increases but amplifying to methane, $\mathrm{CO}$ and NMVOCs increases (Shindell et al., 2005, 2009; Stevenson et al., 2013).

To fully attribute preindustrial to present-day changes in $\mathrm{OH}$, it is necessary to consider changes in other processes that influence $\mathrm{OH}$. Previous studies have shown $\mathrm{OH}$ to be sensitive to biogenic NMVOCs (Wu et al., 2007 and references therein), natural (soil + lightning) $\mathrm{NO}_{\mathrm{x}}$ emissions (Labrador et al., 2004; Steinkamp et al., 2009), and aerosols (Lamarque et al., 2005b; John et al., 2012, Mao et al., 2013). For example, future studies with chemistry-climate models should explore how potential climate and land-use driven changes in biogenic NMVOCs (Lathière et al., 2010) and natural $\mathrm{NO}_{\mathrm{x}}$ emissions since preindustrial times have impacted the present-day $\mathrm{OH}$ abundance and methane lifetime. Furthermore, similar attribution simulations would be helpful in interpreting the influence of each driving factor on $\mathrm{OH}$ and methane lifetime since 1980. The role of stratospheric ozone loss in driving $\mathrm{OH}$ changes over this period is particularly important (e.g., Dentener et al., 2003).

Overall, we show that the multi-model mean $\mathrm{OH}$ abundance has remained nearly constant over the past 150 years. There is, however, large model-to-model variability in the simulated $\mathrm{OH}$ trend, suggesting that a better understanding of the processes influencing atmospheric $\mathrm{OH}$ is needed to reduce uncertainties in its long-term trends and interannual variability (Holmes et al., 2013). We cannot overemphasize the value of accurate observational constraints on $\mathrm{OH}$ (Stone et al., 2012; and references therein), either through direct measurements or by indirect methods using proxies, to improve our understanding of $\mathrm{OH}$ distributions as represented in global models. 


\section{Appendix}

Table A1. Summary of NMVOCs emitted and natural emissions considered in the models.

\begin{tabular}{|c|c|c|c|c|}
\hline \multirow[t]{2}{*}{ Model } & \multirow[t]{2}{*}{ NMVOCs Emitted } & \multicolumn{3}{|c|}{ Natural Emissions } \\
\hline & & $\mathrm{NO}_{\mathrm{x}}$ & $\mathrm{CO}$ & NMVOCs \\
\hline CESM-CAM-superfast & $\mathrm{HCHO}$ and Isoprene & $\begin{array}{l}\text { Interactive lightning } \mathrm{NO}_{\mathrm{x}} \text {, constant } \\
\text { present-day soil } \mathrm{NO}_{\mathrm{x}}\end{array}$ & $\begin{array}{l}\text { Constant present-day oceanic and } \\
\text { soil CO }\end{array}$ & Constant present-day isoprene \\
\hline CICERO-OsloCTM2 & $\begin{array}{l}\text { Alkanes: } \mathrm{C}_{2} \mathrm{H}_{6}, \mathrm{C}_{3} \mathrm{H}_{6}, \mathrm{C}_{3} \mathrm{H}_{8} \text {, lumped } \mathrm{C} 4 / \mathrm{C} 5 \text { alkane, } \\
\text { lumped }>\mathrm{C} 6 \text { alkanes } \\
\text { Alkenes: } \mathrm{C}_{2} \mathrm{H}_{4}, \mathrm{C}_{3} \mathrm{H}_{6} \\
\text { Aromatics: lumped aromatics } \\
\text { Biogenics: isoprene, monoterpenes } \\
\text { OVOCs*: HCHO, lumped }>\mathrm{C} 1 \text { aldehydes (as } \mathrm{CH}_{3} \mathrm{CHO} \text { ), } \\
\text { lumped ketones (as acetone) }\end{array}$ & $\begin{array}{l}\text { Interactive lightning } \mathrm{NO}_{\mathrm{x}} \text {, constant } \\
\text { present-day soil } \mathrm{NO}_{\mathrm{x}}\end{array}$ & $\begin{array}{l}\text { Constant present-day oceanic and } \\
\text { soil CO }\end{array}$ & $\begin{array}{l}\text { Constant present-day } \mathrm{C}_{2} \mathrm{H}_{4} \text {, } \\
\mathrm{C}_{2} \mathrm{H}_{6}, \mathrm{C}_{3} \mathrm{H}_{6}, \mathrm{C}_{3} \mathrm{H}_{8}, \text { acetone, } \\
\text { isoprene, monoterpenes }\end{array}$ \\
\hline CMAM & None & $\begin{array}{l}\text { Interactive lightning } \mathrm{NO}_{\mathrm{x}} \text {, constant } \\
\text { present-day soil } \mathrm{NO}_{\mathrm{x}}\end{array}$ & $\begin{array}{l}\text { Constant soil CO plus } \\
250 \mathrm{Tg} \mathrm{yr}^{-1} \text { as proxy for iso- } \\
\text { prene oxidation, constant oceanic } \\
\mathrm{CO}\end{array}$ & None \\
\hline EMAC & $\begin{array}{l}\text { Alkanes: } \mathrm{C}_{2} \mathrm{H} 6, \mathrm{C}_{3} \mathrm{H}_{8}, \text { lumped } \geq \mathrm{C} 4 \text { alkanes } \\
\text { Alkenes: } \mathrm{C}_{2} \mathrm{H}_{4}, \mathrm{C}_{3} \mathrm{H}_{6}, \text { lumped } \geq \mathrm{C} 4 \text { alkenes } \\
\text { Biogenics: isoprene } \\
\text { OVOCs: } \mathrm{HCHO}, \mathrm{CH} 3 \mathrm{OH} \text {, acetone, } \mathrm{CH}_{3} \mathrm{COOH}, \mathrm{CH}_{3} \mathrm{CHO} \text {, } \\
\text { methyl ethyl ketone (MEK), HCOOH }\end{array}$ & $\begin{array}{l}\text { Interactive lightning } \mathrm{NO}_{\mathrm{x}} \text {, climate- } \\
\text { sensitive soil } \mathrm{NO}_{\mathrm{x}}\end{array}$ & $\begin{array}{l}\text { Constant present-day oceanic and } \\
\text { soil CO }\end{array}$ & $\begin{array}{l}\text { Constant present-day alka- } \\
\text { nes, alkenes, } \mathrm{CH}_{3} \mathrm{COOH} \text {, } \\
\text { acetone, } \mathrm{CH}_{3} \mathrm{OH}, \quad \mathrm{HCOOH} \text {, } \\
\text { climate-sensitive isoprene }\end{array}$ \\
\hline GEOSCCM & $\begin{array}{l}\text { Alkanes: } \mathrm{C}_{2} \mathrm{H}_{6}, \mathrm{C}_{3} \mathrm{H}_{8} \text {, lumped } \geq \mathrm{C} 4 \text { alkanes } \\
\text { Alkenes: } \mathrm{C}_{2} \mathrm{H}_{4}, \text { lumped } \geq \mathrm{C} 3 \text { alkenes } \\
\text { Biogenics: isoprene } \\
\text { OVOCs: } \mathrm{HCHO}, \mathrm{CH}_{3} \mathrm{CHO} \text {, lumped }>\mathrm{C} 3 \text { ketones }\end{array}$ & $\begin{array}{l}\text { Fixed lightning } \mathrm{NO}_{\mathrm{x}} \text {, climate- } \\
\text { sensitive soil } \mathrm{NO}_{\mathrm{x}}\end{array}$ & $\begin{array}{l}\text { No oceanic } \mathrm{CO} \text {, climate-sensitive } \\
\text { CO from biogenic methanol and } \\
\text { monoterpene oxidation }\end{array}$ & $\begin{array}{l}\text { Climate-sensitive isoprene and } \\
\text { lumped } \geq \mathrm{C} 3 \text { alkenes (scaled to } \\
\text { isoprene) }\end{array}$ \\
\hline GFDL-AM3 & $\begin{array}{l}\text { Alkanes: } \mathrm{C}_{2} \mathrm{H}_{6}, \mathrm{C}_{3} \mathrm{H}_{8} \text {, lumped } \geq \mathrm{C} 4 \text { alkanes } \\
\text { Alkenes: } \mathrm{C}_{2} \mathrm{H}_{4}, \text { lumped } \geq \mathrm{C} 3 \text { alkenes } \\
\text { Biogenics: isoprene, monoterpenes } \\
\text { OVOCs: } \mathrm{HCHO}, \mathrm{CH}_{3} \mathrm{OH}, \mathrm{C}_{2} \mathrm{H}_{5} \mathrm{OH} \text {, acetone }\end{array}$ & $\begin{array}{l}\text { Interactive lightning } \mathrm{NO}_{\mathrm{x}} \text { (scaled } \\
\text { to produce } \sim 3-5 \mathrm{TgN} \text { ), constant } \\
\text { preindustrial soil } \mathrm{NO}_{\mathrm{x}}\end{array}$ & $\begin{array}{l}\text { Constant present-day oceanic and } \\
\text { soil CO }\end{array}$ & $\begin{array}{l}\text { Constant present-day alkanes, } \\
\text { alkenes, isoprene, monoter- } \\
\text { penes, } \mathrm{CH}_{3} \mathrm{OH}, \quad \mathrm{C}_{2} \mathrm{H}_{5} \mathrm{OH}, \\
\text { acetone }\end{array}$ \\
\hline GISS-E2-R (-TOMAS) & $\begin{array}{l}\text { Alkanes: } \mathrm{C}_{2} \mathrm{H}_{6}, \mathrm{C}_{3} \mathrm{H}_{8}, \mathrm{C}_{4} \mathrm{H}_{10}, \mathrm{C}_{5} \mathrm{H}_{12}, \text { lumped } \geq \mathrm{C} 6 \text { alka- } \\
\text { nes } \\
\text { Alkenes/alkynes: } \mathrm{C}_{2} \mathrm{H}_{4}, \mathrm{C}_{3} \mathrm{H}_{6}, \text { lumped } \geq \mathrm{C} 3 \text { alkenes, and } \\
\text { lumped } \geq \mathrm{C} 2 \text { alkynes } \\
\text { Biogenics: isoprene, monoterpenes } \\
\text { OVOCs: } \mathrm{HCHO} \text {, acetone, lumped } \geq \mathrm{C} 2 \text { aldehydes }\end{array}$ & $\begin{array}{l}\text { Interactive lightning } \mathrm{NO}_{\mathrm{x}} \text {, constant } \\
\text { present-day soil } \mathrm{NO}_{\mathrm{x}}\end{array}$ & No oceanic and soil CO & $\begin{array}{l}\text { Climate-sensitive isoprene } \\
\text { and monoterpenes based on } \\
\text { present-day vegetation, constant } \\
\text { present-day alkanes, alkenes }\end{array}$ \\
\hline HadGEM2 & $\begin{array}{l}\text { Alkanes: } \mathrm{C}_{2} \mathrm{H}_{6}, \mathrm{C}_{3} \mathrm{H}_{8} \\
\text { OVOCs: } \mathrm{HCHO}, \mathrm{CH} 3 \mathrm{CHO} \text {, acetone }\end{array}$ & $\begin{array}{l}\text { Interactive lightning } \mathrm{NO}_{\mathrm{x}} \text {, constant } \\
\text { soil } \mathrm{NO}_{\mathrm{x}}\end{array}$ & $\begin{array}{l}\text { Constant CO emissions of } 450 \\
\mathrm{Tg} / \text { year as proxy for isoprene ox- } \\
\text { idation, constant oceanic }\end{array}$ & None \\
\hline LMDzORINCA & $\begin{array}{l}\text { Alkanes: } \mathrm{C}_{2} \mathrm{H}_{6}, \mathrm{C}_{3} \mathrm{H}_{8}, \text { lumped } \geq \mathrm{C} 4 \text { alkanes } \\
\text { Alkenes/alkynes: } \mathrm{C}_{2} \mathrm{H}_{4}, \mathrm{C}_{3} \mathrm{H}_{6}, \text { lumped } \geq \mathrm{C} 4 \text { alkenes, } \mathrm{C}_{2} \mathrm{H}_{2} \\
\text { Aromatics: lumped aromatics } \\
\text { Biogenics: isoprene, monoterpenes } \\
\text { OVOCs: HCHO, } \mathrm{CH}_{3} \mathrm{OH}, \quad \mathrm{CH}_{3} \mathrm{CHO}, \quad \mathrm{C}_{2} \mathrm{H}_{5} \mathrm{OH} \text {, } \\
\mathrm{CH}_{3} \mathrm{COOH} \text {, acetone, MEK, methyl vinyl ketone (MVK) }\end{array}$ & $\begin{array}{l}\text { Interactive lightning } \mathrm{NO}_{\mathrm{x}} \text {, constant } \\
\text { present-day soil } \mathrm{NO}_{\mathrm{x}}\end{array}$ & $\begin{array}{l}\text { Constant present-day oceanic } \\
\mathrm{CO} \text {, no soil CO }\end{array}$ & $\begin{array}{l}\text { Constant present-day isoprene, } \\
\text { monoterpenes, } \mathrm{CH}_{3} \mathrm{OH}, \mathrm{C}_{2} \mathrm{H}_{6}, \\
\mathrm{C}_{3} \mathrm{H}_{8}, \mathrm{C}_{2} \mathrm{H}_{4}, \mathrm{C}_{3} \mathrm{H}_{6}, \text { lumped } \\
\geq \mathrm{C} 4 \text { alkenes, } \mathrm{C}_{2} \mathrm{H}_{2} \text {, and ace- } \\
\text { tone }\end{array}$ \\
\hline MIROC-CHEM & $\begin{array}{l}\text { Alkanes: } \mathrm{C}_{2} \mathrm{H}_{6}, \mathrm{C}_{3} \mathrm{H}_{8} \text {, } \\
\text { Alkenes: } \mathrm{C}_{2} \mathrm{H}_{4}, \mathrm{C}_{3} \mathrm{H}_{6} \\
\text { Biogenics: isoprene and monoterpenes } \\
\text { OVOCs: } \mathrm{CH}_{3} \mathrm{OH}, \mathrm{CH}_{3} \mathrm{CHO} \text {, acetone } \\
\text { Other: a lumped species (ONMV) representing (higher alka- } \\
\text { nes/alkenes, alcohols, ketone, and esters) }\end{array}$ & $\begin{array}{l}\text { Interactive lightning } \mathrm{NO}_{\mathrm{x}} \text {, constant } \\
\text { present-day soil } \mathrm{NO}_{\mathrm{x}}\end{array}$ & $\begin{array}{l}\text { Constant present-day oceanic } \\
\mathrm{CO} \text {, no soil CO }\end{array}$ & $\begin{array}{l}\text { Constant present-day alkanes, } \\
\text { alkenes, isoprene, monoter- } \\
\text { penes, acetone, } \mathrm{CH}_{3} \mathrm{CHO} \text {, and } \\
\text { ONMV }\end{array}$ \\
\hline MOCAGE & $\begin{array}{l}\text { Alkanes: } \mathrm{C}_{2} \mathrm{H}_{6}, \mathrm{C}_{3} \mathrm{H}_{8}, \mathrm{C}_{4} \mathrm{H}_{10}, \mathrm{C}_{5} \mathrm{H}_{12} \text {, lumped } \geq \mathrm{C} 6 \text { alka- } \\
\text { nes } \\
\text { Alkenes: } \mathrm{C}_{2} \mathrm{H}_{4}, \mathrm{C}_{3} \mathrm{H}_{6} \\
\text { Aromatics: benzene, toluene, trimethyl benzene, xylene, } \\
\text { lumped other aromatics } \\
\text { Biogenics: isoprene } \\
\text { OVOCs: HCHO, lumped acids, lumped alcohols, lumped } \\
\geq \mathrm{C} 2 \text { aldehydes, lumped esters, lumped ethers, lumped ke- } \\
\text { tones } \\
\text { Other: lumped other VOCs }\end{array}$ & $\begin{array}{l}\text { Interactive lightning } \mathrm{NO}_{\mathrm{x}} \text {, constant } \\
\text { present-day soil } \mathrm{NO}_{\mathrm{x}}\end{array}$ & $\begin{array}{l}\text { Constant present-day oceanic and } \\
\text { soil CO }\end{array}$ & $\begin{array}{l}\text { Constant present-day isoprene } \\
\text { and others }\end{array}$ \\
\hline NCAR-CAM3.5 & $\begin{array}{l}\text { Alkanes: } \mathrm{C}_{2} \mathrm{H}_{6}, \mathrm{C}_{3} \mathrm{H}_{8} \text {, lumped } \geq \mathrm{C} 4 \text { alkanes } \\
\text { Alkenes: } \mathrm{C}_{2} \mathrm{H}_{4}, \mathrm{C}_{3} \mathrm{H}_{6} \text {, lumped } \geq \mathrm{C} 4 \text { alkenes } \\
\text { Biogenics: isoprene, monoterpenes } \\
\text { Aromatics: lumped aromatics (as toluene) } \\
\text { OVOCs: } \mathrm{CH}_{3} \mathrm{OH}, \mathrm{C}_{2} \mathrm{H}_{5} \mathrm{OH}, \mathrm{HCHO}, \mathrm{CH}_{3} \mathrm{CHO} \text {, acetone }\end{array}$ & $\begin{array}{l}\text { Interactive lightning } \mathrm{NO}_{\mathrm{x}} \text { (scaled } \\
\text { to produce } \sim 3-5 \mathrm{TgN} \text { ), constant } \\
\text { preindustrial soil } \mathrm{NO}_{\mathrm{x}}\end{array}$ & $\begin{array}{l}\text { Constant present-day oceanic and } \\
\text { soil CO }\end{array}$ & $\begin{array}{l}\text { Constant present-day isoprene, } \\
\text { monoterpenes, } \mathrm{C}_{2} \mathrm{H}_{4}, \mathrm{C}_{3} \mathrm{H}_{6}, \\
\mathrm{C}_{2} \mathrm{H}_{6}, \mathrm{C}_{3} \mathrm{H}_{8}, \text { acetone, and } \\
\mathrm{CH}_{3} \mathrm{OH}\end{array}$ \\
\hline STOC-HadAM3 & $\begin{array}{l}\text { Alkanes: } \mathrm{C}_{2} \mathrm{H}_{6}, \mathrm{C}_{3} \mathrm{H}_{8}, \mathrm{n}-\mathrm{C}_{4} \mathrm{H}_{10} \\
\text { Alkenes: } \mathrm{C}_{2} \mathrm{H}_{4}, \mathrm{C}_{3} \mathrm{H}_{6} \\
\text { Aromatics: toluene, o-xylene } \\
\text { Biogenics: isoprene } \\
\text { OVOCs: } \mathrm{CH}_{3} \mathrm{OH}, \mathrm{HCHO}, \mathrm{CH}_{3} \mathrm{CHO} \text {, acetone }\end{array}$ & $\begin{array}{l}\text { Interactive lightning } \mathrm{NO}_{\mathrm{x}} \text {, constant } \\
\text { present-day soil } \mathrm{NO}_{\mathrm{x}}\end{array}$ & $\begin{array}{l}\text { Constant present-day oceanic and } \\
\text { soil CO }\end{array}$ & $\begin{array}{l}\text { Climate-sensitive isoprene and } \\
\text { constant present-day alkanes, } \\
\text { alkenes, and OVOCs }\end{array}$ \\
\hline TM5 & $\begin{array}{l}\text { Alkanes: lumped as paraffins (PAR) } \\
\text { Alkenes: lumped as olefins (OLE), } \\
\text { OVOCs: HCHO, lumped } \geq \mathrm{C} 2 \text { aldehydes (as ALD2), } \\
\mathrm{CH}_{3} \mathrm{COCHO} \text {, isoprene }\end{array}$ & $\begin{array}{l}\text { Interactive lightning } \mathrm{NO}_{\mathrm{x}} \text { (scaled } \\
\text { to produce } \sim 5.5-6 \mathrm{Tg} \mathrm{N} \text { ), constant } \\
\text { soil } \mathrm{NO}_{\mathrm{x}}\end{array}$ & $\begin{array}{l}\text { Constant present-day oceanic and } \\
\text { soil CO }\end{array}$ & $\begin{array}{l}\text { Constant present-day alkanes, } \\
\text { alkenes, and isoprene }\end{array}$ \\
\hline UM-CAM & $\begin{array}{l}\text { Alkanes: } \mathrm{C}_{2} \mathrm{H}_{6}, \mathrm{C}_{3} \mathrm{H}_{8}, \\
\text { Biogenics: isoprene } \\
\text { OVOCs: } \mathrm{HCHO}, \mathrm{CH}_{3} \mathrm{CHO} \text {, acetone, isoprene }\end{array}$ & $\begin{array}{l}\text { Interactive lightning } \mathrm{NO}_{\mathrm{x}} \text {, constant } \\
\text { present-day soil } \mathrm{NO}_{\mathrm{x}}\end{array}$ & $\begin{array}{l}\text { Constant present-day oceanic and } \\
\text { soil CO }\end{array}$ & Constant present-day isoprene \\
\hline
\end{tabular}

* OVOCs refers to oxygenated volatile organic compounds. 


\section{Supplementary material related to this article is available online at: http://www.atmos-chem-phys.net/13/ 5277/2013/acp-13-5277-2013-supplement.pdf.}

Acknowledgements. ACCMIP is organized under the auspices of Atmospheric Chemistry and Climate (AC\&C), a project of International Global Atmospheric Chemistry (IGAC) and Stratospheric Processes And their Role in Climate (SPARC) under the International Geosphere-Biosphere Project (IGBP) and World Climate Research Program (WCRP). The authors are grateful to the British Atmospheric Data Centre (BADC), which is part of the NERC National Centre for Atmospheric Science (NCAS), for collecting and archiving the ACCMIP data.

For CESM-CAM-superfast, DB and PC were funded by the US Dept. of Energy (BER), performed under the auspices of LLNL under Contract DE-AC52-07NA27344, and used the supercomputing resources of NERSC under contract No. DE-AC02-05CH11231.

The CICERO-OSloCTM2 simulations were done within the projects SLAC (Short Lived Atmospheric Components) and EarthClim funded by the Norwegian Research Council.

DP would like to thank the Canadian Foundation for Climate and Atmospheric Sciences for their long-running support of CMAM development.

For EMAC, the work of VE and MR was funded by the DLR Earth System Model Validation (ESMVal) project and used the supercomputing resources of the German Climate Computing Center (DKRZ) and the Leibniz Supercomputing Centre (LRZ), and the work of IC was funded by the ENEA National Integrated Model to support the international negotiation on atmospheric pollution (Minni) project.

The GEOSCCM work was supported by the NASA Modeling, Analysis and Prediction program, with computing resources provided by NASA's High-End Computing Program through the NASA Advanced Supercomputing Division.

VN and LWH acknowledge efforts of GFDL's Global Atmospheric Model Development Team in the development of the GFDL-AM3 and Modeling Services Group for assistance with data processing.

AV, DTS and YHL acknowledge support from the NASA MAP and ACMAP programs.

For HadGEM2, WJC, GAF, and STR were supported by the Joint DECC and Defra Integrated Climate Programme (GA01101).

The LMDzORINCA simulations were done using computing resources provided by the CCRT/GENCI computer center of the CEA.

The MIROC-CHEM calculations were performed on the NIES supercomputer system (NEC SX-8R), and supported by the Environment Research and Technology Development Fund (S-7) of the Ministry of the Environment, Japan.

The MOCAGE simulations were supported by Météo-France and CNRS. Supercomputing time was provided by Météo-France/DSI supercomputing center.

The CESM project, including NCAR-CAM3.5, is supported by the National Science Foundation and the Office of Science (BER) of the US Department of Energy. The National Center for Atmospheric
Research is operated by the University Corporation for Atmospheric Research under sponsorship of the National Science Foundation.

The STOC-HadAM3 work made use of the facilities of HECToR, the UK's national high-performance computing service which is funded by the Office of Science and Technology through EPSRC's High End Computing Programme.

The TM5 simulations were performed on the high-performance computing facility of the European Centre for Medium-Range Weather Forecasts (ECMWF).

For UM-CAM, GZ acknowledges NIWA HPCF facility and funding from New Zealand Ministry of Science and Innovation.

We are grateful to Jasmin John and Jingqiu Mao for reviewing an earlier version of this manuscript. Comments by two anonymous reviewers on the manuscript are most appreciated.

Edited by: D. Spracklen

\section{References}

Archibald, A. T., Cooke, M. C., Utembe, S. R., Shallcross, D. E., Derwent, R. G., and Jenkin, M. E.: Impacts of mechanistic changes on $\mathrm{HO}_{\mathrm{x}}$ formation and recycling in the oxidation of isoprene, Atmos. Chem. Phys., 10, 8097-8118, doi:10.5194/acp-108097-2010, 2010.

Barkley, M. P., Palmer, P. I., Ganzeveld, L., Arneth, A., Hågberg, D., Karl, T., Guenther, A., Paulot, F., Wennberg, P. O., Mao, J., Kurosu, T. P., Chance, K., Muller, J.-F., De Smedt, I.,Van Roozendael, M., Chen, D., Wang, Y., and Yantosca, R. M.: Can a state of the art chemistry transport model simulate Amazonian tropospheric chemistry?, J. Geophys. Res., 16, D16302, doi:10.1029/2011JD015893, 2011.

Berntsen, T. K., Isaksen, I. S. A., Myhre, G., Fuglestvedt, J. S., Stordal, F., Larsen, T. A., Freckleton, R. S., and Shine, K. P.: Effects of anthropogenic emissions on tropospheric ozone and its radiative forcing, J. Geophys. Res., 102, 28101-28126, doi:10.1029/97JD02226, 1997.

Bousquet, P., Hauglustaine, D. A., Peylin, P., Carouge, C., and Ciais, P.: Two decades of $\mathrm{OH}$ variability as inferred by an inversion of atmospheric transport and chemistry of methyl chloroform, Atmos. Chem. Phys., 5, 2635-2656, doi:10.5194/acp-52635-2005, 2005.

Bousserez, N., Attié, J. L., Peuch, V. H., Michou, M., Pfister, G., Edwards, D., Emmons, L., Mari, C., Barret, B., Arnold, S. R., Heckel, A., Richert, A., Schlager, H., Lewis, A., Avery, M., Sachse, G., Browell, E. V., and Hair, J. W.: Evaluation of the MOCAGE chemistry transport model during the ICARTT/ITOP experiment, J. Geophys., Res., 112, doi:10.1029/2006JD007595, 2007.

Bowman, K. W., Shindell, D. T., Worden, H. M., Lamarque, J.F., Young, P. J., Stevenson, D. S., Qu, Z., de la Torre, M., Bergmann, D., Cameron-Smith, P. J., Collins, W. J., Doherty, R., Dalsøren, S. B., Faluvegi, G., Folberth, G., Horowitz, L. W., Josse, B. M., Lee, Y. H., MacKenzie, I. A., Myhre, G., Nagashima, T., Naik, V., Plummer, D. A., Rumbold, S. T., Skeie, R. B., Strode, S. A., Sudo, K., Szopa, S., Voulgarakis, A., Zeng, G., Kulawik, S. S., Aghedo, A. M., and Worden, J. R.: Evaluation of ACCMIP outgoing longwave radiation from tropospheric ozone us- 
ing TES satellite observations, Atmos. Chem. Phys., 13, 40574072, doi:10.5194/acp-13-4057-2013, 2013.

Butler, T. M., Taraborelli, D., Brühl, C., Fischer, H., Harder, H., Martinez, M., Williams, J., Lawrence, M. G., and Lelieveld, J.: Improved simulations of isoprene oxidation chemistry from the ECHAM5/MESSy chemistry-climate model: Lessons from the GABRIEL airborne field campaign, Atmos. Chem. Phys., 8, 4529-4546, doi:10.5194/acp-8-4529-2008, 2008.

Chen, S., Ren, X., Mao, J., Chen, Z., Brune, W. H., Lefer, B., Rappenglück, B., Flynn, J., Olson, J., Crawford, J. H.: A comparison of chemical mechanisms based on TRAMP-2006 field data, Atmos. Environ., 44, 4116-4125, 2010.

Crutzen, P. J.: A discussion of the chemistry of some minor constituents in the stratosphere and troposphere, Pure Appl. Geophys., 106-108, 1385-1399, 1973.

Crutzen, P. J. and Brühl, C.: A model study of atmospheric temperatures and the concentrations of ozone, hydroxyl, and some other photochemically active gases during the glacial, the preindustrial, Holocene, and the present, Geophys. Res. Lett., 20, 11, 1047-1050, 1993.

Dalsøren, S. B. and Isaksen, I. S. A.: CTM study of changes in tropospheric hydroxyl distribution 1990-2001 and its impact on methane, Geophys. Res. Lett., 33, L23811, doi:10.1029/2006GL027295, 2006.

Deeter, M. N., Edwards, D. P., Gille, J. C., Emmons, L. K., Francis, G., Ho, S.-P., Mao, D., Masters, D., Worden, H., Drummond, J. R., and Novelli, P. C.: The MOPITT version 4 CO product: Algorithm enhancements, validation, and long-term stability, J. Geophys. Res., 115, D07306, doi:10.1029/2009JD013005, 2010.

Dentener, F., Peters, W., Krol, M., Van Weele, M., Bergamaschi, P., and Lelieveld, J.: Interannual variability and trend of $\mathrm{CH}_{4}$ lifetime as a measure for $\mathrm{OH}$ changes in the 1979-1993 time period, J. Geophys. Res., 108, 4442, doi:10.1029/2002JD002916, 2003.

Derwent, R. G., Collins, W. J., Johnson, C. E., and Stevenson, D. S.: Transient behaviour of tropospheric ozone precursors in a global 3-D CTM and their indirect greenhouse effects, Clim. Change, 49, 463-487, 2001.

Dillon T. J. and Crowley, J. N.: Direct detection of $\mathrm{OH}$ formation in the reactions of $\mathrm{HO}_{2}$ with $\mathrm{CH}_{3} \mathrm{C}(\mathrm{O}) \mathrm{O}_{2}$ and other substituted peroxy radicals, Atmos. Chem. Phys., 8, 4877-4889, doi:10.5194/acp-8-4877-2008, 2008.

Duncan, B. N. and Logan, J. A.: Model analysis of the factors regulating the trends and variability of carbon monoxide between 1988 and 1997, Atmos. Chem. Phys., 8, 7389-7403, doi:10.5194/acp-8-7389-2008, 2008.

Duncan, B. N, Logan, J. A., Bey, I., Megretskaia, I. A., Yantosca, R. M., Novelli, P. C., Jones, N. B., and Rinsland, C. P.: Global budget of CO, 1988-1997: Source estimates and validation with a global model, J. Geophys. Res. 112, D22301, doi:10.1029/2007JD008459, 2007.

Emmerson, K. M. and Evans, M. J.: Comparison of tropospheric gas-phase chemistry schemes for use within global models, Atmos. Chem. Phys., 9, 1831-1845, doi:10.5194/acp-9-1831-2009, 2009.

Emmons, L. K., Edwards, D. P., Deeter, M. N., Gille, J. C., Campos, T., Nédélec, P., Novelli, P., and Sachse, G.: Measurements of Pollution In The Troposphere (MOPITT) validation through 2006, Atmos. Chem. Phys., 9, 1795-1803, doi:10.5194/acp-91795-2009, 2009.
Fiore, A. M., West, J. J., Horowitz, L. W., Naik, V., and Schwarzkopf, M. D.: Characterizing the tropospheric ozone response to methane emission controls and the benefits to climate and air quality, J. Geophys. Res., 113, D08307, doi:10.1029/2007JD009162, 2008.

Fiore, A. M., Dentener, F. J.,Wild, O., Cuvelier, C., Schultz, M. G., Hess, P., Textor, C., Schulz, M., Doherty, R. M., Horowitz, L. W., MacKenzie, I. A., Sanderson, M. G., Shindell, D. T., Stevenson, D. S., Szopa, S., Van Dingenen, R., Zeng, G., Atherton, C., Bergmann, D., Bey, I., Carmichael, G., Collins, W. J., Duncan, B. N., Faluvegi, G., Folberth, G., Gauss, M., Gong, S., Hauglustaine, D., Holloway, T., Isaksen, I. S. A., Jacob, D. J., Jonson, J. E., Kaminski, J.W., Keating, T. J., Lupu, A., Marmer, E., Montanaro, V., Park, R. J., Pitari, G., Pringle, K. J., Pyle, J. A., Schroeder, S., Vivanco, M. G., Wind, P., Wojcik, G., Wu, S., and Zuber, A.: Multi-model estimates of intercontinental sourcereceptor relationships for ozone pollution, J. Geophys. Res., 114, D04301, doi:10.1029/2008JD010816, 2009.

Granier, C., Bessagnet, B., Bond, T., D’Angiola, A., v. d. Gon, H. D., Frost, G. J., Heil, A., Kaiser, J. W., Kinne, S., Klimont, Z., Kloster, S., Lamarque, J.-F., Liousse, C., Masui, T., Meleux, F., Mieville, A., Ohara, T., Raut, J.-C., Riahi, K., Schultz, M. G., Smith, S. J., Thomson, A., van Aardenne, J., van der Werf, G. R., and van Vuuren, D. P.: Evolution of anthropogenic and biomass burning emissions of air pollutants at global and regional scales during the 1980-2010 period, Clim. Change, 109, 163-190, doi:10.1007/s10584-011-0154-1, 2011.

Grant, A., Archibald, A. T., Cooke, M. C., and Shallcross, D. E.: Modelling the oxidation of seventeen volatile organic compounds to track yields of $\mathrm{CO}$ and $\mathrm{CO}_{2}$, Atmos. Environ., 44, 3797-3804, 2010.

Grenfell, J. L., Shindell, D. T., Koch, D., and Rind, D.: Chemistryclimate interactions in the Goddard Institute general circulation model. 2. New insights into modeling the pre-industrial atmosphere, J. Geophys. Res., 106, 33435-33451, 2001.

Hameed, S., Pinto, J. P., and Stewart, R. W.: Sensitivity of the predicted $\mathrm{CO}-\mathrm{OH}-\mathrm{CH}_{4}$ perturbation to tropospheric $\mathrm{NO}_{\mathrm{x}}$ concentrations, J. Geophys. Res., 84, 763-768, 1979.

Hauglustaine, D. A. and Brasseur, G. P.: Evolution of tropospheric ozone under anthropogenic activities and associated radiative forcing of climate, J. Geophys. Res., 106, 32337-32360, doi:10.1029/2001JD900175, 2001.

Hess, P. and Mahowald, N.: Interannual variability in hindcasts of atmospheric chemistry: the role of meteorology, Atmos. Chem. Phys., 9, 5261-5280, doi:10.5194/acp-9-5261-2009, 2009.

Hofzumahaus, A., Rohrer, F., Lu, K., Bohn, B., Brauers, T., Chang, C.-C., Fuchs, H., Holland, F., Kita, K., Kondo, Y., Li, X., Lou, S., Shao, M., Zeng, L. Wahner, A., and Zhang, Y.: Amplified trace gas removal in the troposphere, Science, 324, 1702-1704, 2009.

Holloway, T. E, Levy II, H., and Kasibhatla, P.: Global distribution of carbon monoxide, J. Geophys. Res., 105, 12123-12147, 2000.

Holmes, C. D., Prather, M. J., Søvde, O. A., and Myhre, G.: Future methane, hydroxyl, and their uncertainties: key climate and emission parameters for future predictions, Atmos. Chem. Phys., 13, 285-302, doi:10.5194/acp-13-285-2013, 2013.

Jacob, D. J.: Introduction to atmospheric chemistry, Princeton University Press, 199-231, 1999.

Jiang, J. H., Su, H., Zhai, C., Perun, V., Del Genio, A., Nazarenko, L. S., Donner, L. J., Horowitz, L. Seman, C., Cole, J., Get- 
telman, A., Ringer, M. A., Rotstayn, L., Jeffery, S.,Wu, Tongwen, Brient, F., Dufresne, J.-L., Kawai, H., Koshiro, T., Watanabe, M., Lecuyer, T. S., Volodin, E. M., Iversen, T., Drange, H., Mesquita, M. D. S., Read,W. G.,Waters, J.W., Tian, B., Teixeira, and Stephens, G. L.: Evaluation of Cloud and Water Vapor Simulations in CMIP5 Climate Models Using NASA "ATrain" Satellite Observations, J. Geophys. Res, 117, D14105, doi:10.1029/2011JD017237, 2012.

John, J., Fiore, A. M., Naik, V., Horowitz, L. W., and Dunne, J. P.: Climate versus emission drivers of methane lifetime from 1860 2100, Atmos. Chem. Phys., 12, 12021-12036, doi:10.5194/acp12-12021-2012, 2012.

Johnson, C. E., Stevenson, D. S., Collins, W. J., and Derwent, R. G.: Role of climate feedback on methane and ozone studies with a coupled Ocean-Atmosphere-Chemistry model, Geophys. Res. Lett., 28, 1723-1726, 2001.

Karlsdóttir, S. and Isaksen, I. S. A.: Changing methane lifetimepossible cause for reduced growth, Geophys. Res. Lett., 27, 9396, 2000.

Krol, M. and Lelieveld, J.: Can the variability in tropospheric $\mathrm{OH}$ be deduced from measurements of 1,1,1-trichloroethane (methyl chloroform)?, J. Geophys. Res., 108, 4125, doi:10.1029/2002JD002423, 2003.

Krol, M., van Leeuwen, P. J., and Lelieveld, J.: Global OH trend inferred from methyl-3 chloroform measurements, J. Geophys. Res., 103, 10697-10711, 1998.

Labrador, L. J., von Kuhlmann, R., and Lawrence, M. G.: Strong sensitivity of the global mean $\mathrm{OH}$ concentration and the tropospheric oxidizing efficiency to the source of $\mathrm{NO}_{\mathrm{x}}$ from lightning, Geophys. Res. Lett., 31, L06102, doi:10.1029/2003GL019229, 2004.

Lamarque, J.-F., Hess, P., Emmons, L. K., Buja, L., Washington, W., and Granier, C.: Tropospheric ozone evolution between 1890 and 1990, J. Geophys. Res., 110, D08304, doi:10.1029/2004JD005537, 2005a.

Lamarque, J.-F., Kiehl, J. T., Hess, P. G., Collins, W. D., Emmons, L. K., Ginoux, P., Luo, C., and Tie, X. X.: Response of a coupled chemistry-climate model to changes in aerosol emissions: Global impact on the hydrological cycle and the tropospheric burden of $\mathrm{OH}$, ozone, and $\mathrm{NO}_{\mathrm{x}}$, Geophys. Res. Lett., 32, L16809, doi:10.1029/2005GL023419, 2005b.

Lamarque, J.-F., Bond, T. C., Eyring, V., Granier, C., Heil, A., Klimont, Z., Lee, D., Liousse, C., Mieville, A., Owen, B., Schultz, M. G., Shindell, D., Smith, S. J., Stehfest, E., Van Aardenne, J., Cooper, O. R., Kainuma, M., Mahowald, N., McConnell, J. R., Naik, V., Riahi, K., and van Vuuren, D. P.: Historical (1850-2000) gridded anthropogenic and biomass burning emissions of reactive gases and aerosols: methodology and application, Atmos. Chem. Phys., 10, 7017-7039, doi:10.5194/acp10-7017-2010, 2010.

Lamarque, J.-F., Shindell, D. T., Josse, B., Young, P. J., Cionni, I., Eyring, V., Bergmann, D., Cameron-Smith, P., Collins, W. J., Doherty, R., Dalsøren, S., Faluvegi, G., Folberth, G., Ghan, S. J., Horowitz, L. W., Lee, Y. H., MacKenzie, I. A., Nagashima, T., Naik, V., Plummer, D., Righi, M., Rumbold, S., Schulz, M., Skeie, R. B., Stevenson, D. S., Strode, S., Sudo, K., Szopa, S., Voulgarakis, A., and Zeng, G.: The Atmospheric Chemistry and Climate Model Intercomparison Project (ACCMIP): overview and description of models, simulations and climate diagnostics,
Geosci. Model Dev., 6, 179-206, doi:10.5194/gmd-6-179-2013, 2013.

Lathière, J., Hewitt, C. N., and Beerling, D. J.: Sensitivity of isoprene emissions from the terrestrial biosphere to 20th century changes in atmospheric $\mathrm{CO}_{2}$ concentration, climate, and land use, Global Biogeochem. Cy., 24, GB1004, doi:10.1029/2009GB003548, 2010.

Lawrence, M. G., Jöckel, P., and von Kuhlmann, R.: What does the global mean $\mathrm{OH}$ concentration tell us?, Atmos. Chem. Phys., 1, 37-49, doi:10.5194/acp-1-37-2001, 2001.

Lee, Y. H., Lamarque, J.-F., Flanner, M. G., Jiao, C., Shindell, D. T., Berntsen, T., Bisiaux, M. M., Cao, J., Collins, W. J., Curran, M., Edwards, R., Faluvegi, G., Ghan, S., Horowitz, L. W., McConnell, J. R., Myhre, G., Nagashima, T., Naik, V., Rumbold, S. T., Skeie, R. B., Sudo, K., Takemura, T., and Thevenon, F.: Evaluation of preindustrial to present day black carbon and its albedo forcing from ACCMIP (Atmospheric Chemistry and Climate Model Intercomparison Project), Atmos. Chem. Phys., 13, 2607-2634, doi:10.5194/acp-13-2607-2013, 2013.

Lelieveld, J., Peters, W., Dentener, F. J., and Krol, M. C.: Stability of tropospheric hydroxyl chemistry, J. Geophys. Res., 107, 4715, doi:10.1029/2002JD002272, 2002.

Lelieveld, J., Dentener, F. J., Peters, W., and Krol, M. C.: On the role of hydroxyl radicals in the self-cleansing capacity of the troposphere, Atmos. Chem. Phys., 4, 2337-2344, doi:10.5194/acp4-2337-2004, 2004.

Lelieveld, J., Butler, T. M., Crowley, J. N., Dillon, T. J., Fischer, H., Ganzeveld, L., Harder, H., Lawrence, M. G., Martinez, M., Taraborrelli, D., and Williams, J.: Atmospheric oxidation capacity sustained by a tropical forest, Nature, 452, 737-740, doi:10.1038/nature06870, 2008.

Levy, H.: Normal atmosphere: Large radical and formaldehyde concentrations predicted, Science, 173, 141-143, 1971.

Liu, H., Crawford, J. H., Pierce, R. B., Norris, P., Platnick, S. E., Chen, G., Logan, J. A., Yantosca, R. M., Evans, M. J., Kittaka, C., Feng, Y., and Tie, X.: Radiative effect of clouds on tropospheric chemistry in a global three-dimensional chemical transport model, J. Geophys. Res., 111, D20303, doi:10.1029/2005JD006403, 2006.

Logan, J. A., Prather, M. J., Wofsy, S. C., and McElroy, M. B.: Tropospheric chemistry: A global perspective, J. Geophys. Res., 86, 7210-7354, 1981.

Loulergue, L., Schilt, A., Spahni, R., Masson-Delmotte, V., Blunier, T., Benedicte, L., Barnola, J.-M., Raynaud, D., Stocker, T. F., and Chappellaz, J.: Orbital and millennial-scale features of atmospheric $\mathrm{CH}_{4}$ over the past 800,000 years, Nature 453,383 386, 2008.

Luecken, D. J., Phillips, S., Sarwar, G., and Jang, C.: Effects of using the CB05 vs. SAPRC99 vs. CB4 chemical mechanism on model predictions: ozone and gas-phase photochemical precursor concentrations, Atmos. Environ., 42, 5805-5820, 2008.

Mao, J., Fan, S., Jacob, D. J., and Travis, K. R.: Radical loss in the atmosphere from $\mathrm{Cu}-\mathrm{Fe}$ redox coupling in aerosols, Atmos. Chem. Phys., 13, 509-519, doi:10.5194/acp-13-509-2013, 2013.

Martinerie, P., Brasseur, G. P., and Granier, C.: The chemical composition of ancient atmospheres: A model study constrained by ice core data, J. Geophys. Res., 100, 14291-14304, 1995.

Meinshausen, M., Smith, S. J., Calvin, K. V., Daniel, J. S., Kainuma, M., Lamarque, J.-F., Matsumoto, K., Montzka, S. A., Raper, S. 
C. B., Riahi, K., Thomson, A. M., Velders, G. J. M., and van Vuuren, D.: The RCP Greenhouse Gas Concentrations and their Extension from 1765 to 2300, Clim. Change (Special Issue), 109, 213-241, doi:10.1007/s10584-011-0156-z, 2011.

Mickley, L. J., Murti, P. P., Jacob, D. J., Logan, J. A., Koch, D. M., and Rind, D.: Radiative forcing from tropospheric ozone calculated with a unified chemistry climate model, J. Geophys. Res., 104, 30153-30172, 1999.

Monteil, G., Houweling, S., Dlugockenky, E. J., Maenhout, G., Vaughn, B. H., White, J. W. C., and Röckmann, T.: Interpreting methane variations in the past two decades using measurements of $\mathrm{CH}_{4}$ mixing ratio and isotopic composition, Atmos. Chem. Phys., 11, 9141-9153, doi:10.5194/acp-11-9141-2011, 2011.

Montzka, S. A. and Fraser, P. J.: Controlled substances and other source gases, in Scientific Assessment of Ozone Depletion: 2002, Global Ozone Res. and Monitor. Proj. Rep.47, chap. 1, 498 pp., World Meteorol. Organ., Geneva, Switzerland, 2003.

Montzka, S. A., Spivakovsky, C. M., Butler, J. H., Elkins, J. W., Lock, L. T., and Mondeel, D. J.: New observational constraints, for atmospheric hydroxyl on global and hemispheric scales, Science, 288, 500-503, 2000.

Montzka, S. A., Krol, M., Dlugokencky, E., Hall, B., Jöckel, P., and Lelieveld, J.: Small interannual variability of global atmospheric hydroxyl, Science, 331, 67-69, doi:10.1126/science.1197640, 2011.

Naik, V., Mauzerall, D., Horowitz, L. W., Schwarzkopf, D., Ramaswamy, V., and Oppenheimer, M.: Net radiative forcing due to changes in regional emissions of tropospheric ozone precursors, J. Geophys. Res., 110, D24306, doi:10.1029/2005JD005908, 2005.

Novelli, P. C. and Masarie, K. A.: Atmospheric Carbon Monoxide Dry Air Mole Fractions from the NOAA ESRL Carbon Cycle Cooperative Global Air Sampling Network, 1988-2009, Version: 2011-10-14, path: ftp://ftp.cmdl.noaa.gov/ccg/co/flask/ event/ (last access: 11 April 2012), 2010.

Paulot, F., Crounse, J. D., Kjaergaard, H. G., Kurten, A., St. Clair, J. M., Seinfeld, J. H., and Wennberg, P. O.: Unexpected epoxide formation in the gas-phase photooxidation of isoprene, Science, 325, 730-733, doi:10.1126/science.1172910, 2009.

Peeters, J., Nguyen, T. L., and Vereecken, L.: HOx radical regeneration in the oxidation of isoprene, Phys. Chem. Chem. Phys., 11, 5935-5939, doi:10.1039/b908511d, 2009.

Petit, J. R., Jouzel, J., Raynaud, D., Barkov, N. I., Barnola, J. -M., Basile, I., Bender, M., Chappellaz, J., Davis, M., Delaygue, G., Delmotte, M., Kotlaykov, V. M., Legrand, M., Lipenkov, V. Y., Lorius, C., Pepin, L., Ritz, C., Saltzman, E., and Stievenard, M.: Climate and atmospheric history of the past 420,000 years from the Vostock ice core, Antarctica, Nature, 399, 429-436, 1999.

Pinto, J. P. and Khalil, M. A. K.: The stability of tropospheric $\mathrm{OH}$ during ice gases, interglacial epochs and modern times, Tellus, 43B, 347-352, 1991.

Prather, M. and Spivakovsky, C.M.: Tropospheric OH and the lifetimes of hydrochlorofluorocarbons, J. Geophys. Res., 95, 1872318729, doi:10.1029/JD095iD11p18723, 1990.

Prather, M. J.: Lifetimes and Eigenstates in Atmospheric Chemistry, Geophys. Res. Lett. 21, 801-804, 1994.

Prather, M., Ehhalt, D., Dentener, F., Derwent, R. G., Dlugokencky, E., Holland, E., Isaksen, I. S. A., Katima, J., Kirchhoff, V., Matson, P., Midgley, P. M., and Wang, M.: Chapter 4. Atmospheric
Chemistry and Greenhouse Gases, in Climate Change 2001: The Scientific Basis, edited by: Houghton, J. T., Ding, Y., Griggs, D. J., Noguer, M., van der Linden, P. J., Dai, X., Maskell, K., Johnson, C. A., Cambridge U. Press, 239-287, 2001.

Prather, M., Holmes, C., and Hsu, J.: Reactive greenhouse gas scenarios: systematic exploration of uncertainties and the role of atmospheric chemistry, Geophys. Res. Lett., 39, L09803, doi:10.1029/2012GL051440, 2012.

Prather, M. J.: Time scales in atmospheric chemistry: Theory, GWPs for $\mathrm{CH}_{4}$ and $\mathrm{CO}$, and runaway growth, Geophys. Res. Lett., 23, 2597-2600, 1996.

Prinn, R. G., Weiss, R. F., Miller, B. R., Huang, J., Alyea F. N., Cunnold, D. M., Fraser, P. J., Hartley, D. E., and Simmonds, P. G.: Atmospheric trends and lifetime of $\mathrm{CH}_{3} \mathrm{CCl}_{3}$ and global $\mathrm{OH}$ concentrations, Science, 269, 187-192, 1995.

Prinn, R. G., Weiss, R. F., Fraser, P. J., Simmonds, P. G., Cunnold, D. M., Alyea, F. N., O'Doherty, S., Salameh, P., R. Miller, B., Huang, J., Wang, R. H. J., Hartley, D. E., Harth, C., Steele, L. P., Sturrock, G., Midgley, P. M., and McCulloch, A.: A history of chemically and radiatively important gases in air deduced from ALE/GAGE/AGAGE, J. Geophys. Res., 105, 1775117792, 2000.

Prinn, R. G., Huang, J., Weiss, R. F., Cunnold, D. M., Fraser, P. J., Simmonds, P. G., McCulloch, A., Harth, C., Salameh, P., O'Doherty, S., Wang, R. H. J., Porter, L, and Miller, B. R.: Evidence for substantial variations of atmospheric hydroxyl radicals over the past two decades, Science, 292, 1882-1888, 2001.

Prinn, R. G., Huang, J., Weiss, R. F., Cunnold, D. M., Fraser, P. J., Simmonds, P. G., McCulloch, A., Harth, C., Reimann, S., Salameh, P., O’Doherty, S., Wang, R. H. J., Porter, L. W., Miller, B. R., and Krummel, P. B.: Evidence for variability of atmospheric hydroxyl radicals over the past quarter century, Geophys. Res. Lett., 32, L07809, doi:10.1029/2004GL022228, 2005.

Rohrer, F. and Berresheim, H.: Strong correlation between levels of tropospheric hydroxyl radicals and solar ultraviolet radiation, Nature, 442, 184-187, 2006.

Sander, S. P., Abbatt, J., Barker, J. R., Burkholder, J. B., Friedl, R. R., Golden, D. M., Huie, R. E., Kolb, C. E., Kurylo, M. J., Moortgat, G. K., Orkin, V. L., Wine, P. H.: Chemical kinetics and photochemical data for use in atmospheric studies: Evaluation number 17, JPL Publication 10-6, Jet Propulsion Laboratory, Pasadena, CA, USA, 2011.

Sapart, S. J., Monteil, G., Prokopiou, M., van de Wal, R. S. W., Kaplan, J. O., Sperlich, P., Krumhardt, K. M., van der Veen, C., Houweling, S., Krol, M. C., Blunier, T., Sowers, T., Martinerie, P., Witrant, E., Dahl-Jensen, D., and Röckmann, T.: Natural and anthropogenic variations in methane sources during the past two millennia, Nature, 490, 85-88, doi:10.1038/nature11461, 2012.

Shindell, D. T., Faluvegi, G., and Bell, N.: Preindustrial-to-present day radiative forcing by tropospheric ozone from improved simulations with the GISS chemistry-climate GCM. Atmos. Chem. Phys., 3, 1675-1702, doi:10.5194/acp-3-1675-2003, 2003.

Shindell, D. T., Faluvegi, G., Bell, N., and Schmidt, G. A.: An emissions-based view of climate forcing by methane and tropospheric ozone, Geophys. Res. Lett., 32, L04803, doi:10.1029/2004GL021900, 2005.

Shindell, D. T., Faluvegi, Koch, D. M., Schmidt, G. A., Unger, N., and Bauer, S. E.: Improved attribution of climate forcing to emissions, Science, 326, 716-718, doi:10.1126/science.1174760, 
2009.

Shindell, D. T., Faluvegi, G., Unger, N., Aguilar, E., Schmidt, G. A., Koch, D. M., Bauer, S. E., and Miller, R. L.: Simulations of preindustrial, present-day, and 2100 conditions in the NASA GISS composition and climate model G-PUCCINI, Atmos. Chem. Phys., 6, 4427-4459, doi:10.5194/acp-6-4427-2006, 2006a.

Shindell, D. T., Faluvegi, G., Stevenson, D. S., Krol, M. C., Emmons, L. K., Lamarque, J.-F., Petron, G., Dentener, F. J., Ellingsen, K., Schultz, M. G., Wild, O., Amann, M., Atherton, C. S., Bergmann, D. J., Bey, I., Butler, T., Cofala, J., Collins, W. J., Derwent, R. G., Doherty, R. M., Drevet, J., Eskes, H. J., Fiore, A. M., Gauss, M., Hauglustaine, D. A., Horowitz, L. W., Isaksen, I. S. A., Lawrence, M. G., Montanaro, V., Müller, J.-F., Pitari, G., Prather, M. J., Pyle, J. A., Rast, S., Rodriguez, J. M., Sanderson, M. G., Savage, N. H., Strahan, S. E., Sudo, K., Szopa, S., Unger, N., van Noije, T. P. C., and Zeng, G.: Multimodel simulations of carbon monoxide: Comparison with observations and projected near-future changes, J. Geophys. Res., 111, D19306, doi:10.1029/2006JD007100, 2006b.

Shindell, D. T., Lamarque, J.-F., Schulz, M., Flanner, M., Jiao, C., Chin, M., Young, P. J., Lee, Y. H., Rotstayn, L., Mahowald, N., Milly, G., Faluvegi, G., Balkanski, Y., Collins, W. J., Conley, A. J., Dalsøren, S., Easter, R., Ghan, S., Horowitz, L., Liu, X., Myhre, G., Nagashima, T., Naik, V., Rumbold, S. T., Skeie, R., Sudo, K., Szopa, S., Takemura, T., Voulgarakis, A., Yoon, J.-H., and Lo, F.: Radiative forcing in the ACCMIP historical and future climate simulations, Atmos. Chem. Phys., 13, 2939-2974, doi:10.5194/acp-13-2939-2013, 2013.

Skeie, R. B., Berntsen, T. K., Myhre, G., Tanaka, K., Kvalevåg, M. M., and Hoyle, C. R.: Anthropogenic radiative forcing time series from pre-industrial times until 2010, Atmos. Chem. Phys., 11, 11827-11857, doi:10.5194/acp-11-11827-2011, 2011.

Sofen, E. D., Alexander, B., and Kunasek, S. A.: The impact of anthropogenic emissions on atmospheric lifetime, production pathways, oxidants, and ice core $\Delta^{17} \mathrm{O}\left(\mathrm{SO}_{4}^{2-}\right)$, Atmos. Chem. Phys., 11, 3565-3578, doi:10.5194/acp-11-3565-2011, 2011.

Spivakovsky, C. M., Logan, J. A., Montzka, S. A., Balkanski, Y. J., Foreman-Fowler, M., Jones, D. B. A., Horowitz, L. W., Fusco, A. C., Brenninkmeijer, C. A. M., Prather, M. J., Wofsy, S. C., and McElroy, M. B.: Three-dimensional climatological distribution of tropospheric $\mathrm{OH}$ : Update and evaluation, J. Geophys. Res., 105, 8931-8980, 2000.

Staffelbach, T., Neftel, A., Stauffer, B., and Jacob, D.: A record of the atmospheric methane sink from formaldehyde in polar ice cores, Nature, 349, 603-605, doi:10.1038/349603a0, 1991.

Stavrakou, T., Peeters, J., and Müller, J.-F.: Improved global modelling of $\mathrm{HO}_{\mathrm{x}}$ recycling in isoprene oxidation: Evaluation against the GABRIEL and INTEX-A aircraft campaign measurements, Atmos. Chem. Phys., 10, 9863-9878, doi:10.5194/acp-10-98632010, 2010.

Steinkamp, J., Ganzeveld,, L. N., Wilcke, W., and Lawrence, M. G.: Influence of modeled soil biogenic NO emissions on related trace gases and the atmospheric oxidizing efficiency, Atmos. Chem. Phys., 9, 2663-2677, doi:10.5194/acp-9-2663-2009, 2009.

Stevenson, D. S., Johnson, C. E., Collins, W. J., Derwent, R. G., and Edwards, J. M.: Future tropospheric ozone radiative forcing and methane turnover - the impact of climate change, Geophys. Res. Lett. 27, 2073-2076, 2000.
Stevenson, D. S., Doherty, R. M., Sanderson, M. G., Collins, W. J., Johnson, C. E., and Derwent, R. G.: Radiative forcing from aircraft $\mathrm{NO}_{\mathrm{x}}$ emissions: mechanisms and seasonal dependence, J. Geophys. Res. 109, D17307, doi:10.1029/2004JD004759, 2004.

Stevenson, D. S., Dentener, F. J., Schultz, M. G., Ellingsen, K., van Noije, T. P. C., Wild, O., Zeng, G., Amann, M., Atherton, C. S., Bell, N., Bergmann, D. J., Bey, I., Butler, T., Cofala, J., Collins, W. J., Derwent, R. G., Doherty, R M., Drevet, J., Eskes, H. J., Fiore, A. M., Gauss, M., Hauglustaine, D. A., Horowitz, L. W., Isaksen, I. S. A., Krol, M. C., Lamarque, J., Lawrence, M. G., Montanaro, V., Müller, J., Pitari, G., Prather, M. J., Pyle, J. A., Rast, S., Rodriguez, J. M., Sanderson, M. G., Savage, N. H., Shindell, D. T., Strahan, S. E., Sudo, K., and Szopa, S.: Multi-model ensemble simulations of present day and near-future tropospheric ozone, J. Geophys. Res., 111, D08301, doi:10.1029/2005JD006338, 2006.

Stevenson, D. S., Young, P. J., Naik, V., Lamarque, J.-F., Shindell, D. T., Voulgarakis, A., Skeie, R. B., Dalsøren, S. B., Myhre, G., Berntsen, T. K., Folberth, G. A., Rumbold, S. T., Collins, W. J., MacKenzie, I. A., Doherty, R. M., Zeng, G., van Noije, T. P. C., Strunk, A., Bergmann, D., Cameron-Smith, P., Plummer, D. A., Strode, S. A., Horowitz, L., Lee, Y. H., Szopa, S., Sudo, K., Nagashima, T., Josse, B., Cionni, I., Righi, M., Eyring, V., Conley, A., Bowman, K. W., Wild, O., and Archibald, A.: Tropospheric ozone changes, radiative forcing and attribution to emissions in the Atmospheric Chemistry and Climate Model Intercomparison Project (ACCMIP), Atmos. Chem. Phys., 13, 3063-3085, doi:10.5194/acp-13-3063-2013, 2013.

Stone, D., Whalley, L. K., and Dwayne, E. H.: Tropospheric OH and $\mathrm{HO}_{2}$ radicals: field measurements and model comparisons, Chem. Soc. Rev., 41, 6348-6404, doi:10.1039/c2cs35140d, 2012.

Thompson, A. M.: The oxidizing capacity of the Earth's atmosphere: Probable past and future changes, Science, 256, 1157 1165, 1992.

Voulgarakis, A., Wild, O., Savage, N. H., Carver, G. D., and Pyle, J. A.: Clouds, photolysis and regional tropospheric ozone budgets, Atmos. Chem. Phys., 9, 8235-8246, doi:10.5194/acp-98235-2009, 2009.

Voulgarakis, A., Naik, V., Lamarque, J.-F., Shindell, D. T., Young, P. J., Prather, M. J., Wild, O., Field, R. D., Bergmann, D., CameronSmith, P., Cionni, I., Collins, W. J., Dalsøren, S. B., Doherty, R. M., Eyring, V., Faluvegi, G., Folberth, G. A., Horowitz, L. W., Josse, B., MacKenzie, I. A., Nagashima, T., Plummer, D. A., Righi, M., Rumbold, S. T., Stevenson, D. S., Strode, S. A., Sudo, K., Szopa, S., and Zeng, G.: Analysis of present day and future $\mathrm{OH}$ and methane lifetime in the ACCMIP simulations, Atmos. Chem. Phys., 13, 2563-2587, doi:10.5194/acp-13-25632013, 2013.

Wang, Y. and Jacob, J. D.: Anthropogenic forcing on tropospheric ozone and $\mathrm{OH}$ since preindustrial times, J. Geophys. Res., 103 31123-31135, 1998.

West, J. J., Fiore, A. M., Naik, V., Horowitz, L. W., Schwarzkopf, M. D., and Mauzerall, D. L.: Ozone air quality and radiative forcing consequences of changes in ozone precursor emissions, Geophys. Res. Lett., 34, L06806, doi:10.1029/2006GL029173, 2007.

Whalley, L. K., Edwards, P. M., Furneaux, K. L., Goddard, A., Ingham, T., Evans, M. J., Stone, D., Hopkins, J. R., Jones, C. E., Karunaharan, A., Lee, J. D., Lewis, A. C., Monks, P. S., Moller, 
S. J., and Heard, D. E.: Quantifying the magnitude of a missing hydroxyl radical source in a tropical rainforest, Atmos. Chem. Phys., 11, 7223-7233, doi:10.5194/acp-11-7223-2011, 2011.

Wild, O., Prather M. J., and Akimoto, H.: Indirect long-term global cooling from $\mathrm{NO}_{\mathrm{x}}$ emissions, Geophys. Res. Lett., 28, 17191722, 2001.

Wong, S., Wang, W.-C., Isaksen, I. S. A., Berntsen, T. K., and Sundet, J. K.: A global climate-chemistry model study of present day tropospheric chemistry and radiative forcing from changes in tropospheric $\mathrm{O}_{3}$ since the preindustrial period, J. Geophys. Res., 109, D11309, doi:10.1029/2003JD003998, 2004.

Wu, S., Mickley, L. J., Jacob, D. J., Logan, J. A., Yantosca, R. M., and Rind, D.: Why are there large differences between models in global budgets of tropospheric ozone?, J. Geophys. Res., 112, D05302, doi:10.1029/2006JD007801, 2007.
Young, P. J., Archibald, A. T., Bowman, K. W., Lamarque, J.-F., Naik, V., Stevenson, D. S., Tilmes, S., Voulgarakis, A., Wild, O., Bergmann, D., Cameron-Smith, P., Cionni, I., Collins, W. J., Dalsøren, S. B., Doherty, R. M., Eyring, V., Faluvegi, G., Horowitz, L. W., Josse, B., Lee, Y. H., MacKenzie, I. A., Nagashima, T., Plummer, D. A., Righi, M., Rumbold, S. T., Skeie, R. B., Shindell, D. T., Strode, S. A., Sudo, K., Szopa, S., and Zeng, G.: Pre-industrial to end 21 st century projections of tropospheric ozone from the Atmospheric Chemistry and Climate Model Intercomparison Project (ACCMIP), Atmos. Chem. Phys., 13, 2063-2090, doi:10.5194/acp-13-2063-2013, 2013.

Zimmerman, P. R., Chatfield, R. B., Fishman, J., Crutzen, P. J., and Hanst, P. L.: Estimates of the production of $\mathrm{CO}$ and $\mathrm{H}_{2}$ from the oxidation of hydrocarbon emissions from vegetation, Geophys. Res. Lett., 5, 679-682, 1978. 